Refrence
All106 $04857 ?$
78-1477

Robert W. Beausoliel

William J. Meese

Lawrence S. Galowin

Center for Building Technology National Engineering Laboratory National Bureau of Standards

Washington, D.C. 20234

July 1978

Sponsored by

The Department of Energy

100 Washington, D.C. 20461 

EXPLORATORY STUDY OF TEMPERATURES

PRODUCED BY SELF-HEATING OF

RESIDENTIAL BRANCH CIRCUIT WIRING

WHEN SURROUNDED BY THERMAL

INSULATION

Robert W. Beausoliel

William J. Meese

Lawrence S. Galowin

Center for Building Technology

National Engineering Laboratory

National Bureau of Standards

Washington, D.C. 20234

July 1978

Sponsored by

The Department of Energy

Washington, D.C. 20461

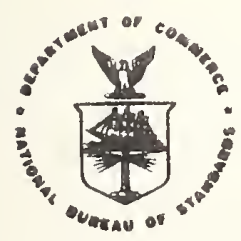

U.S. DEPARTMENT OF COMMERCE, Juanita M. Kreps, Secretary

Dr. Sidney Harman, Under Secretary

Jordan J. Baruch, Assistant Secretary for Science and Technology

NATIONAL BUAEAU OF STANDARDS, Emest Ambler, Director 


\section{SI CONVERSION UNITS}

In view of the present accepted practice in this country for building technology, common U.S. units of measurement have been used throughout this document. In recognition of the position of the United States as a signatory to the General Conference on Weights and Measures, which gave official status to the metric SI system of units in 1960, assistance is given to the reader interested in making use of the coherent system of SI units by giving conversion factors applicable to U.S. units used in this document.

Mass

Length

Temperature
1 pound - mass $\left(1 \mathrm{~b}_{\mathrm{m}}\right)=0.4535924 \mathrm{~kg}$

1 inch $=0.0254$ meter $(\mathrm{m})$

$t($ Celsius $)=5 / 9[t($ Fahr $)-32]$
Torque

Time
1 bf in $=0.113 \mathrm{r}_{2}$ ewton meter $(\mathrm{Nm})$

1 hour $=60$ minutes $=3,600$ seconds 


\section{ACKNOWLEDGEMENTS}

Work on this preliminary study on the overheating of residential branch circuit wiring has been conducted as part of an interdisciplinary framework. The Center for Building Technology (CBT) of the National Bureau of Standards (NBS) is concerned primarily with the heat production and degradation of electrical system performance due to inadequate heat dissipation and penetration of thermal insulating materials into electrical wiring devices.

The Center for Fire Research of NBS is concerned primarily with the potential for combustion and smoldering of building materials due to ignition sources inadvertently created by overheated electrical wiring or devices. This report deals with the electrical-system side of the problem.

The effort reported in this document was jointly funded by the Department of Commerce and the Department of Energy (DoE), under DoE/NBS interagency agreement.

The authors appreciate the recommendations and guidance concerning thermal insulation that were received from Dr. Walter J. Rossiter of the Structures, Materials, and Life Safety Division, CBT, NBS. 
CONTENTS

$\underline{\text { Page }}$

SI Conversion Units ..................... 1

Acknowledgements . . . . . . . . . . . . . . 1 i

Abstract ....................... . . v v

1. Introduction ... . . . . . . . . . . . . . . . 1

1.1 Purpose .................... . . . . 1

1.2 Scope .............................. 2

2. Test Procedure and Results for Attic Installation . . . . . 2

2.1 Temperatures on Parallel Cables in Simulated Attic . . 5

2.1.1 Cables in Open Air............. 5

2.1.2 Cables between Two Layers of Thermal
Insulation. . . . . . . . . . 7

2.1.3 Cables between Four Layers of Thermal

Insulation. ............. . . 9

2.1.4 Cables between Two Layers of Thermal Insulation

Within Simulated Ceiling Joist Space..... . 12

2.2 Temperatures on Single Cables in Simulated Attic . . . 15

2.2.1 Single Nonmetallic-Sheathed Cable Between Two

Layers of Thermal Insulation . . . . . . 15

2.2.2 Single Nonmetallic-Sheathed Cable in Simulated

Ceiling Joist Spaces .......... 15

2.2.3 Single Armored Cable in Simulated Ceiling Joist

Spaces ............ 20

2.2.4 Axial Heat Conduction Along Partially Thermally

Insulated Branch Circuit Wiring....... . 20

2.3 Discussion of Cable Tests in Simulated Attic . . . . . 26

3. Test Procedure and Results for Cables and Outlet Boxes in

Walls .................. . . . . 28

3.1 Temperatures on Cables and Outlet Boxes . . . . . . 29

3.2 Penetration of Thermal Insulation Into Outlet Boxes. . . 32

3.3 Discussion of Tests of Wall Wiring Surrounded by Thermal

Insulation ... . . . . . . . . . . . .

4. Summary . . . . . . . . . . . . . . . . . 37

5. Recommendations . . . . . . . . . . . 38

6. References .................... 41

Appendix A: Calculation of Wire Temperature Based on Increase in Wire Resistance ................. 


\section{CONTENTS (Continued)}

$\underline{\text { Page }}$

Appendix B: Chemistry Tests at NBS for Gases and/or Vapors from Heated Cables and Thermal Insulation ...... 45

Appendix C: Precautions During Installation of "Foamed-in" and "Blown-in" Thermal Insulation ... . . . . . 


\section{EXPLORATORY STUDY OF TEMPERATURES PRODUCED BY SELF-HEATING OF RESIDENTIAL BRANCH CIRCUIT WIRING WHEN SURROUNDED BY THERMAL INSULATION}

R. W. Beausoliel, W. J. Meese, and L. S. Galowin

\section{ABSTRACT}

The purpose of the work presented in this paper was to make preliminary determinations under laboratory conditions of temperatures that might develop on residential electrical wiring covered by thermal insulation when carrying rated currents or currents slightly above rated values.

The results show that temperatures on conductors surrounded by thermal insulation can greatly exceed the maximum service temperature for the wire insulation. Results also show that some types of insulation currently used to retrofit buildings may fill wall outlet boxes and contact the current-carrying elements and connections of duplex receptacles.

This study indicates need for a concentrated study of temperatures that might develop on residential electrical wiring covered by thermal insulation.

Key Words: Branch circuit wiring; electrical fires; heat generation in receptacles; insulated buildings; overheating conductors; residential branch circuit wiring; thermal insulation and electrical wiring. 



\section{INTRODUCTION}

Shortages of fuels for residential heating and severe winter weather have resulted in both State and Federal programs on energy conservation for buildings. Improvements in thermal efficiency of residential buildings through increased use of additional thermal insulation are recommended for new construction and retrofitting existing buildings.

The impact of increased use of building insulation in residences may be detrimental to electrical wire, cables, and devices comprising the residential branch circuits. The conduction of electric current generates heat which is normally dissipated by conduction and convection when reasonably exposed. When the circuits are covered by thermal building insulation the electrical insulation and wire temperatures will increase substantially. The local environment of the thermal insulation is correspondingly raised to increased temperature levels. Present standards and model code $[1,2,3]$ require that the type of electrical insulation usually used in residential branch circuits should not operate at temperatures in excess of $140^{\circ} \mathrm{F}$. The effect of higher temperatures on electrical insulation is of considerable concern. Overheated wiring circuits may ignite electrical insulation or ignite proximate building materials or lead to gradual deterioration of dielectric strength of the insulation which may lead to ignition from arcing or short-circuits.

\subsection{PURPOSE}

The investigation performed in this project was exploratory in order to provide a preliminary basis for assessment of the problems related to additional insulation on the installed building systems. The specific purpose was to establish a basis for other in-depth research. The test program included the following:

1. Determination of typical temperatures generated on residential wiring by rated or slightly higher than rated electric currents* before and after surrounding wiring in building thermal insulation.

2. Evaluation of configurations of residential wiring and building thermal insulation that result in the generation of typically high wire temperatures by rated or slightly higher than rated electric currents*.

* For the purpose of this report "higher than rated electric currents" means currents above rated currents of the wires. However, such currents and times for which data are included in this report are at or below those at which overcurrent devices are normally required to operate, (i.e., it is consistent with the accepted test standards used for approval listing of such overcurrent protection devices). 
3. Determination of the effects of foamed-in and blown-in thermal building insulation which migrates into electrical outlet boxes and the increased temperature effects of such insulation on electrical wiring and wiring devices.

\subsection{SCOPE}

Laboratory tests to obtain the dynamic temperature response were conducted with simple configurations of branch circuit wiring installed in simulated attic and wall spaces. These tests were of an exploratory nature and therefore did not cover all of the conditions that would be encountered in practice.

Because of these restraints and for simplification, the use of electrical connections and wiring configurations was held to a minimum in the work presented in this report. The reduction in temperature caused by heat transfer through connections and along 非 12 AWG conductors contained in nonmetallic-sheathed cables (NMSC) was a part of this preliminary study.

No data concerning actual incidences of fire in thermal insulation or electrical conductor overheating were available for this study.

It was beyond the scope of the preliminary work to study fire potential resulting from loose electrical connections or failure of electrical insulation. Fire potential was concurrently being considered by the Center for Fire Research at NBS.

\section{TEST PROCEDURE AND RESULTS FOR ATTIC INSTALLATION}

For simplification, safety, and energy conservation purposes, testing was done with low supply voltage. The heat generated in the wire at low voltage was the same as it would have been if testing had been done on a 120-volt supply. This exploratory study was concerned primarily with temperatures on wiring and not with the possibility of insulation failure which might be accentuated by use of 120-volt supply.

The low voltage setup as shown in Figure 1 serves only the wiring under test as the load. As shown in Figure 1, the current was controlled with a variable autotransformer connected to the 120-volt building supply and feeding a step-down transformer having a maximum voltage output of 12 volts.

The current readings we re obtained using a $0.001 \mathrm{ohm} \pm 1 \%, 50$ ampere AC shunt, which is part of the digital AC/DC millivol tmeter used during the tests. During some of the tests of this report, the same voltmeter was switched to DC millivolt range in order to read the thermocouple output. During other tests, temperatures we re recorded automatically every five minutes on a data acquisition system using type " $T$ " thermocouples, and current and voltage drop were recorded every five minutes 


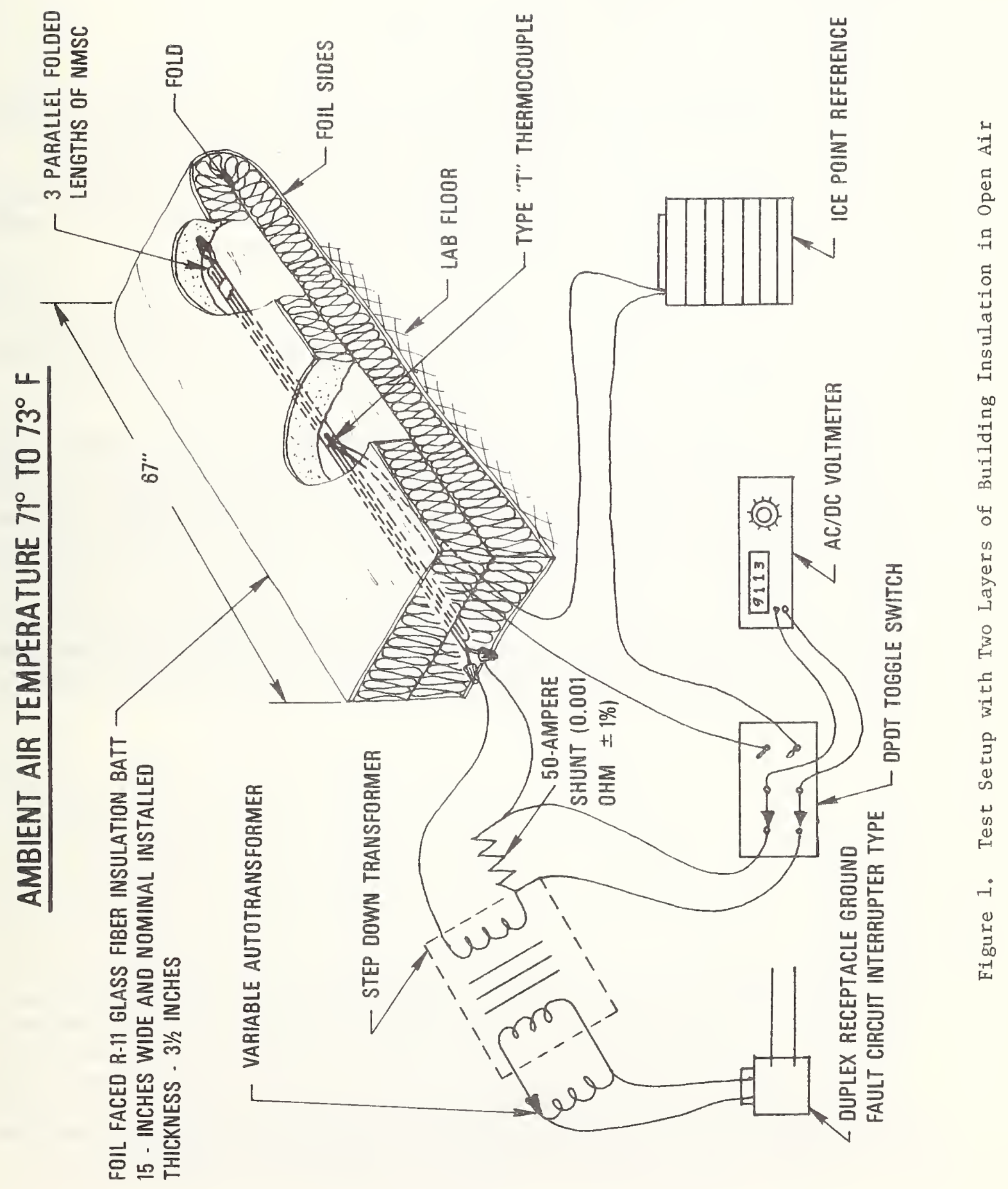


by hand. Current and voltage drop were used to calculate a final wire resistance for the specimen. Using the final resistance and the initial cold resistance, determined with a kelvin bridge ohmmeter, along with the initial temperature, the final temperature of the wire was calculated as a check on temperatures recorded from thermocouples. See Appendix A for details.

The general test procedure was as follows:

(a) Measure the temperature(s) at five-minute intervals and at controlled currents of 10A, 15A, 20A, and at slightly higher currents. The cable was in a structure that simulated a typical wiring condition before insulation was added for energy conservation. The cables were generally either resting on top of the insulation as they might in an attic space or were installed in empty wall stud spaces.

(b) Fill the attic joist space or wall stud space with insulation with recognized " $R$ " values [4] and repeat the temperature measurements of (a) above. Current was recorded every five minutes. Voltage drops were also recorded periodically.

Residential general purpose branch circuits with $60^{\circ} \mathrm{C}$ electrical insulations usually use either 非2 AWG copper or \#14 AWG copper wire. From temperatures and corresponding resistance values in the copper wire tables [5], it was determined that 非12 AWG wire had a slightly greater resistance heating at rated current than $k_{14}$; 112 wiring was general1y used in this work. See Table 1.

The laboratory tests were made to obtain temperatures on residential wiring at current levels that can exist under normally installed conditions. The cables were resting upon or surrounded by aluminum foilfaced glass fiber blanket $(\mathrm{R}-11) *$.

* $\mathrm{R}$ is the resistance value of a typical glass fiber insulation batt of $31 / 2$ inches thickness. One such batt is $\mathrm{R}-11$, two such batts are $\mathrm{R}-22$, etc. The manufacturer states that the product conforms to Federal Specification HH-1-521E Type 111 [6]. The manufacturer also instructs that foil facings may either be removed or slashed freely with a knife when adding to existing attic floor insulation in order to prevent trapping moisture between old and new insulation. 
Table 1 - Resistance heating of 非14 AWG and 非12 AWG copper wire at rated currents respectively $15 \mathrm{~A}$ and $20 \mathrm{~A}$

Temperature $\left({ }^{\circ} \mathrm{C}\right)$

$\begin{array}{ccc} & \text { \#1 } 14 \mathrm{AWG} & \underline{\# 12 \mathrm{AWG}} \\ 20 & 0.567 & 0.636 \\ 25 & 0.578 & 0.648 \\ 50 & 0.634 & 0.712 \\ 75 & 0.691 & 0.772 \\ 100 & 0.747 & 0.836 \\ 200 & 0.970 & 1.084\end{array}$

Resistance Heating (Watts per foot of wire)

\subsection{TEMPERATURES ON PARALLEL CABLES IN SIMULATED ATTIC}

Branch circuit cables are close together in the vicinity where they connect to circuit breaker panels or may be close together when pulled through holes in joists and studs. Several 120-volt 20-ampere branch circuit cables of this type might serve portable window air conditioners or portable electric heat units, and such units could load or nearly load these circuits to their rated current. Two or more building insulation-surrounded cables in close proximity could reach higher operating temperatures than a single insulation-surrounded cable.

\subsubsection{Cables in Open Air}

The nonmetallic-sheathed cable specimen shown in Figure 2 was used to simulate three branch circuits located close together. In this simulation, the cable configurations are probably somewhat closer than would be found in an actual installation; for the purposes of this work, the specimen was considered a worst case. Because of concern for exposure of the laboratory staff to toxic gas or vapor that might possibly evolve from hot cables during such tests, the series of tests with cables located at varying distances from each other were not performed. See Section 2.1.2 discussion concerning the possible gas emission from cables.

The specimen was placed on a batt of $\mathrm{R}-11$ insulation as shown in Figure 1, except that the top batt was folded back to expose the cable to ambient air and simulated some typical installation conditions prior to adding additional thermal insulation for energy conservation. The 


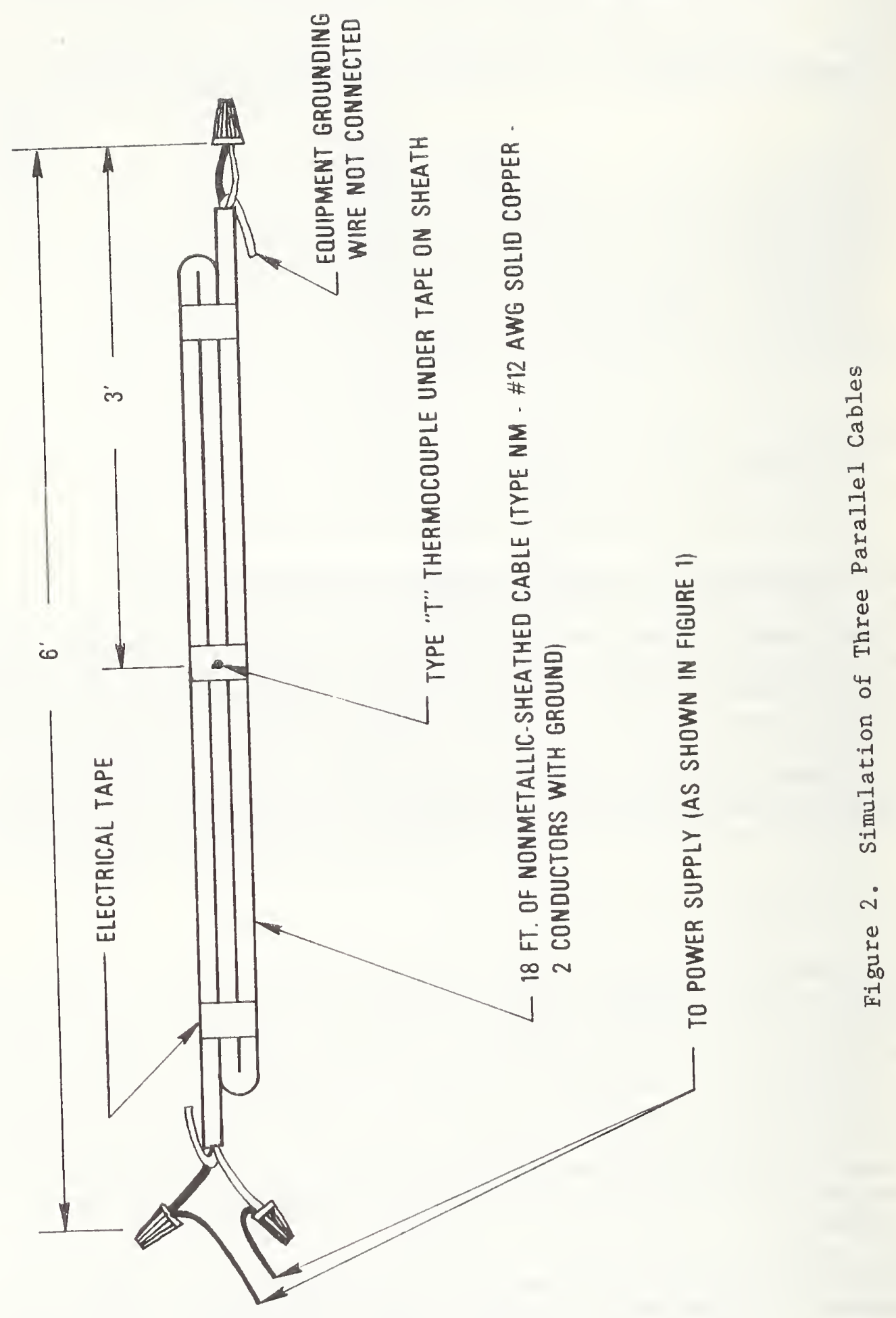


initial cold resistance of the specimen was measured with a kelvin bridge and found to be 0.0577 ohms for 36 feet of $\# 12$ AWG copper wire at $72^{\circ} \mathrm{F}$. A current of $20 \mathrm{~A}$ was applied and controlled with the variable autotransformer to within several tenths of an ampere. At five-minute intervals, current, voltage drop across the specimen, and temperature were recorded and the end of the test was based upon obtaining steady-state temperature readings. The temperature and current record is presented in Table 2. A temperature check based on resistance change is presented in Appendix A.

\section{TABLE 2}

Temperatures on Three Parallel Cables Exposed to Ambient Air with One Layer of R-11 Insulation Under Cables

\section{TIME (MINUTES)}

0

5

10

15

20

25

30

35

40

\section{CURRENT - A}

0

20.0

20.1

20.1

20.3

20.2

20.2

20.2

20.3

\section{TEMPERATURE - ${ }^{\circ} \mathrm{F}$}

72

83

91

96

99

101

103

103

103

\subsubsection{Cables between T'wo Layers of Thermal Insulation}

The purpose of this test was to obtain the difference in temperatures on wiring surrounded by building insulation from wiring open to the air on top of building insulation. The specimen was surrounded by insulation as shown in Figure 1 and the procedure repeated to obtain data presented in Table 3. 
TABLE 3

Temperatures on Three Paralle 1 Cables Placed between Two Layers of R-11 Insulation

\section{TIME (MINUTES)}

0

5

10

15

20

23

25

30

35

40

45

50

55

60

65

70

75

80

85

90

95

100

105

110

1.15

120

125

130

135

140

145

150

\section{CURRENT - A}

0

19.6

19.7

20.0

20.2

20.1

19.7

19.8

20.2

20.0

19.9

20.4

20.3

20.2

20.1

20.2

20.3

20.2

20.2

20.1

20.3

20.3

20.3

20.2

20.3

20.2

20.2

20.2

20.2

20.3

20.2

20.3
TEMPERATURE - ${ }^{\circ} \mathrm{F}$

74
91
107
120
133
141
145
155
164
173
180
187
194
200
206
210
214
217
220
223
225
228
230
231
233
234
235
237
238
238
239
239


It must be recognized that circuit breakers and fuses do not quickly open circuits that are subjected to currents which are slightly overrated. The Underwriters' Laboratories Standard 489 for Molded-Case Circuit Breakers requires circuit breakers to open the circuit within one hour at $135 \%$ of their rated current [7] and the Underwriters ' Standard 198.5 for Plug Fuses requires that fuses operate in one hour at $135 \%$ of rated current [8]. Figure 3 shows typical manufacturer's curves (current versus trip time) for a 20-ampere circuit breaker of residential type. As shown, overloads of $135 \%$ rated current or less can result in relatively long overload periods before the circuit breaker is expected to open the circuit.

Because of the exploratory nature of the work presented in this report, it was not practical to test circuit breakers and fuses in order to gain statistically significant data concerning circuit opening time. However, because of the likelihood that overloads of $120-135 \%$ of rated current can occur, it was decided to determine cable temperatures within this overcurrent range. It is judged that such currents could occur from homeowner-installed window air conditioners or electric space heaters or combined currents from various sources on receptacle circuits. The results of this test are presented in Table 4. As shown, the test duration was only 60 minutes long, to simulate the required clear time for breaker or fuse. It should be noted that the temperature on the cable was still increasing at about $10^{\circ} \mathrm{F}$ per fiveminute period at the end of the test (one hour).

Examination showed that the cable insulation (sheath) did not appear to be damaged (burned or scorched) by the test but the sheath did appear to be somewhat loosened (loss of "elastic" properties) relative to the unexposed or as-received cable. The glass fiber insulation was not discolored by heat and the glass fibers did not stick to the cable sheath. There was an odor of hot plastic when the building insulation was removed for examination of the cable specimen. A burning sensation was experienced in mouth, lips and throat of the investigator during the examination. Also, the sensation was accompanied by nausea. Tests to determine if noxious fumes were given off by cable and/or glass-fiber thermal insulation were inconclusive. See Appendix B.

\subsubsection{Cables between Four Layers of Thermal Insulation}

In order to obtain some insight concerning the effect of additional thermal insulation on cable temperature, the cable was placed on top of two layers of $\mathrm{R}-11$, and two layers of $\mathrm{R}-11$ were placed on top of the cables; otherwise the test setup was identical to that shown in Figure 1 and 2. The results are given in Table 5.

The test was terminated at the 115-minute period due to release of possibly toxic gas or vapor. 


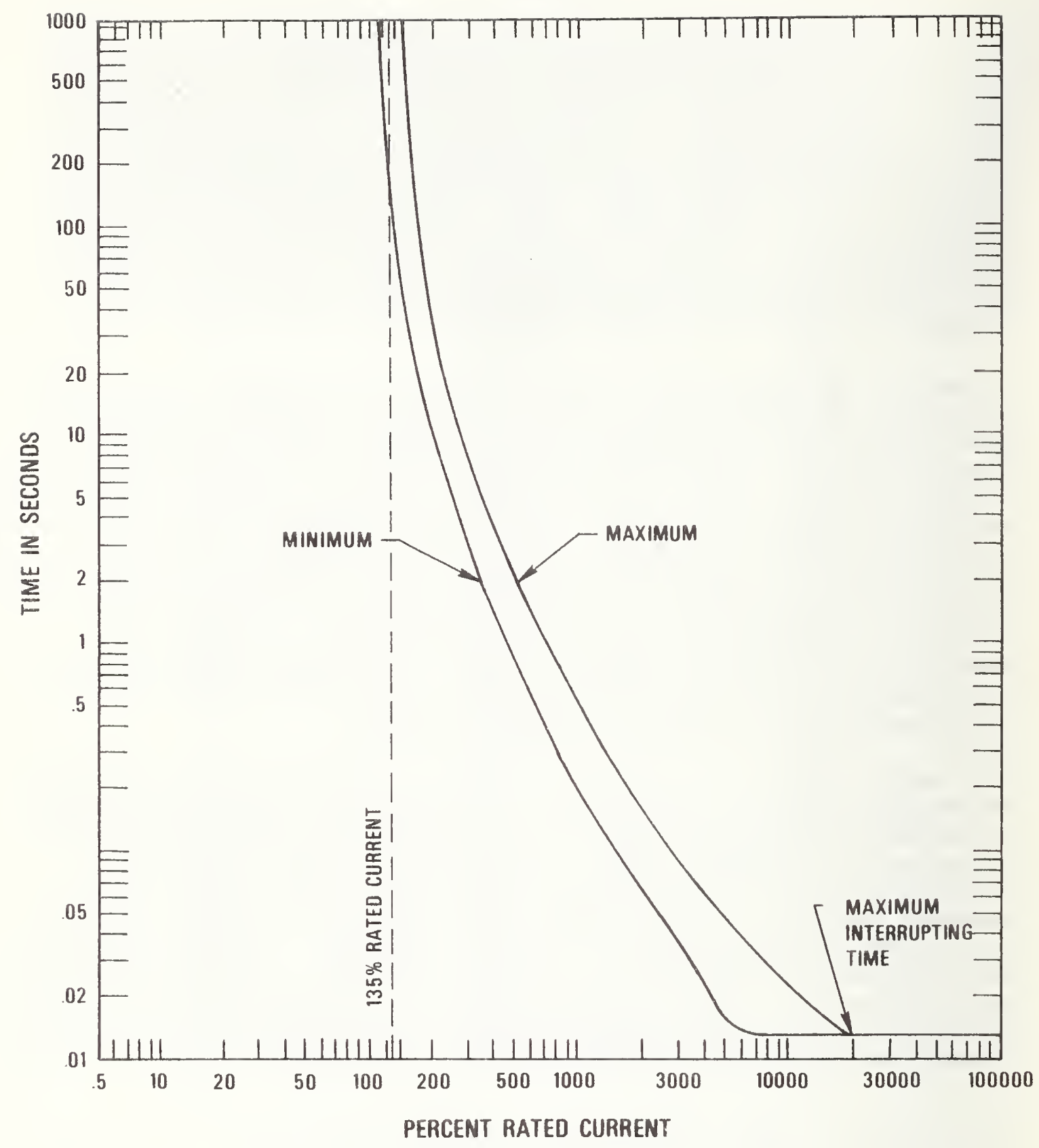

Figure 3. Manufacturer's Curves Applicable to a 20-Ampere Circuit Breaker 
TABLE 4

Temperatures on Three Parallel Cables Carrying 135\% of Rated Current While the Cables Were Located between Two Layers of $\mathrm{R}-11$ Insulation

TIME (MINUTES)

0

5

10

15

20

25

30

35

40

45

50

55

60

\section{CURRENT - A}

0

26.9

27.1

26.9

27.0

27.2

27.0

26.9

26.9

27.1

27.2

27.1

26.8
TEMPERATURE - ${ }^{\circ} \mathrm{F}$

71

100

128

154

178

200

219

237

252

265

278

289

298 
Temperatures on Three Parallel Cables with Two Layers of R-11 under the Cables and Two Layers of $R-11$ on Top of the Cables

\section{TIME (MINUTES)}

15

20

25

30

35

40

45

50

55

60

65

70

75

80

85

90

95

100

105

110

115

\section{CURRENT - A}

0

20.3

20.3

20.1

20.1

20.4

20.4

20.3

20.2

20.2

20.1

20.2

20.2

20.2

$-$

20.1

20.0

20.4

20.4

20.3

20.3

20.2

20.2

\section{TEMPERATURE - ${ }^{\circ} \mathrm{F}$}

70

87

105

117

131

144

156

167

177

186

193

201

207

214

$-$

224

228

233

236

240

243

246

249

2.1.4 Cables between Two Layers of Thermal Insulation within Simulated Ceiling Joist Space

Because the tests presented in Sections 2.1 .1 and 2.1 .2 were carried out with the cable specimen placed between batts of insulation that were placed on the laboratory floor, the effect of the floor on recorded temperatures and the effect of typical building structures on temperatures were questioned. In order to answer this question, the specimen and two layers of insulation were placed in the simulated ceiling joist space shown in Figure 4. The joist space was sixteen inches on center and contained a sheet rock bottom simulating a ceiling. To maintain a flow of air under the ceiling as would exist in an actual building, the ceiling joist arrangement was supported above the floor as shown. Recorded data are presented in Table 6. These data show close agreement with those presented in Table 3; the maximum temperature of Table 6 is only 8 degrees less than that of Table 3. 


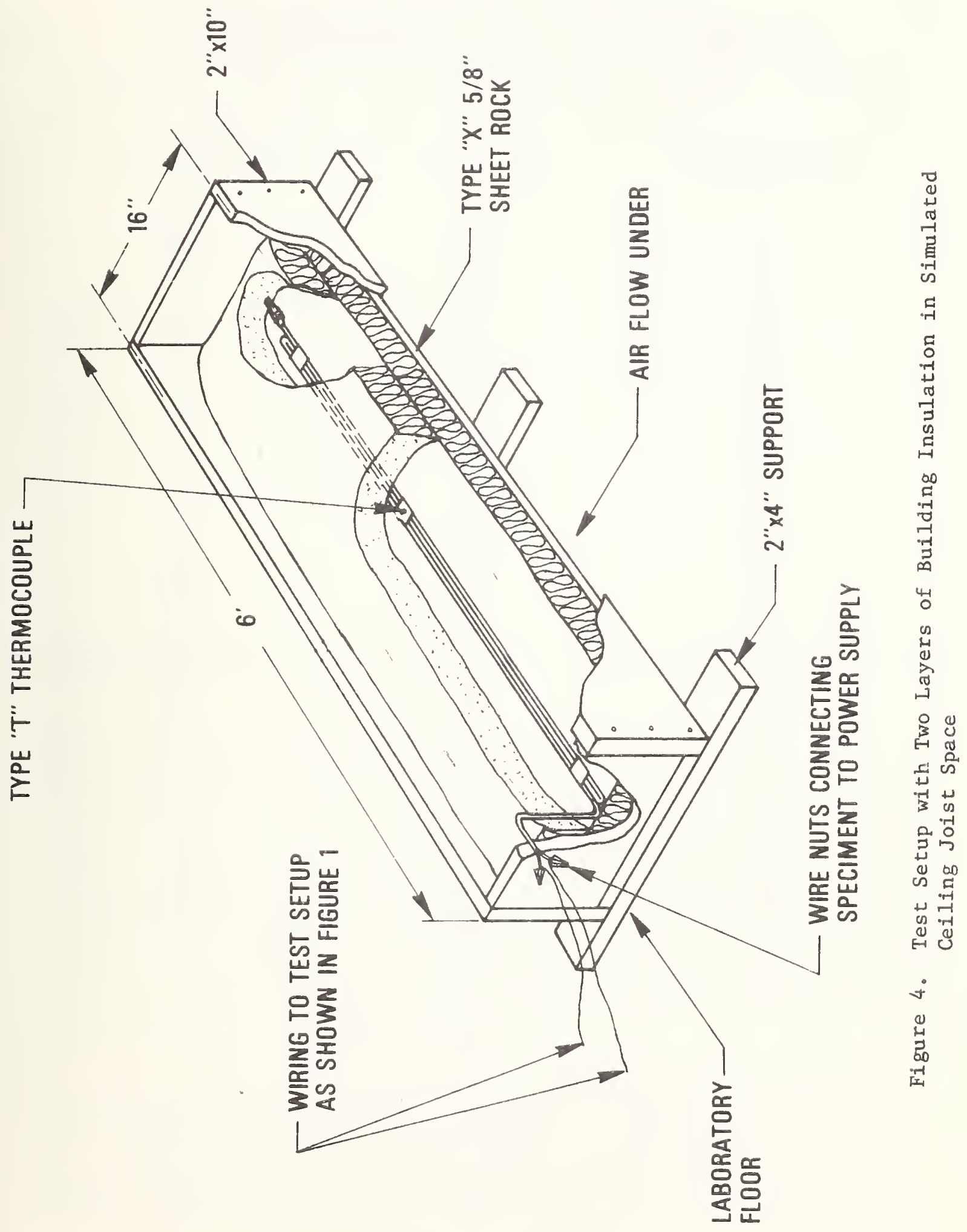


TABLE 6

Temperatures on Three Parallel Cables Placed between

Two Layers of $\mathrm{R}-11$ Insulation in Simulated Ceiling Joist Space

TIME (MINUTES)

0

5

10

15

20

25

30

35

40

45

50

55

60

65

70

75

80

85

90

95

100

105

110

115

120

125

130

140

145

150
CURRENT - A

0

20.0

20.1

20.0

20.0

19.9

20.0

20.0

20.0

20.1

20.1

20.1

20.0

20.0

20.2

20.2

20.1

20.2

20.2

20.1

20.1

20.1

20.2

20.1

20.1

20.1

20.2

20.2

20.1

20.1
TEMPERATURE - ${ }^{\circ} \mathrm{F}$

71

89

106

119

133

144

154

163

172

178

185

191

196

201

205

209

212

215

217

220

221

223

224

226

227

229

230

231

231

231 


\subsection{TEMPERATURES ON SINGLE CABLES IN SIMULATED ATTIC}

A single length of nonmetallic-sheathed cable was tested to compare its temperature for the same current and under the same test conditions used for the paralleled cables previously discussed in Section 2.1. This cable had a length of six feet which is identical to the length of the paralleled group in Figure 1.

2.2.1 Single Nonmetallic-sheathed Cable between Two Layers of Thermal Insulation

A current of 20-amperes was applied to the cable for a period of 95 minutes as shown in Table 7 .

As in the parallel group of cables, the thermocouple was located in the center of the cable.

A current of 27 amperes was applied to the cable for a period of 60 minutes as shown in Table 8 .

2.2.2 Single Nonmetallic-sheathed Cable in Simulated Ceiling Joist Spaces

The tests presented in this section are similar to those in previous sections of this report, but additional temperature measurements were taken and other wiring and structural arrangements considered.

The test setup used for this experiment was a modification of preliminary setup shown in Figure 4, page 13 of this report. An ad jacent joist space was simulated on efther side of the ceiling joist setup of Figure 4. This was accomplished by extending the $2 \times 4$ supports shown for a distance of 16 inches on either side of the joist space. Six-foot long by 15-inch wide by 1/4-inch thick plywood sheets were placed on these supports and 15 -inch wide by $31 / 2-i n c h$ thick batts of glass fiber, $\mathrm{R}-11$, insulation with the foil facing removed, were placed on the sheets. Insulation was also placed at the ends of the joist space. A data acquisition system was used to record temperatures at various time intervals in place of the temperature measuring equipment in Figure 1, page 3. However, current and voltage had to be recorded at time intervals by hand.

Temperature data were taken every five minutes using the nonmetallicsheathed cable specimen shown in Figure 5. Although test runs would last about 90 minutes to obtain steady-state temperature conditions, only the steady-state temperature condition is presented in Table 9. Figure 6 demonstrates highest temperatures as a function of steadystate currents and amount of thermal insulation. 
TABLE 7

Temperatures on a Single Cable Placed between Two Layers of R-11 Insulation

TIME (MINUTES)

0

5

10

15

20

25

30

35

40

45

50

55

60

65

70

75

80

85

90

95

\section{CURRENT - A}

0

19.7

20.2

20.2

20.2

20.1

20.0

20.1

20.2

20.1

20.1

20.1

20.1

20.2

20.0

20.1

20.2

20.3

20.1

20.1
TEMPERATURE $-{ }^{\circ} \mathrm{F}$

74

89

102

111

119

125

130

134

138

140

143

145

147

148

149

150

150

151

151

152

TABLE 8

Temperatures on a Single Cable Carrying $135 \%$ of Rated Current While the Cable was Located between Two Layers of R-11 Insulation

TIME (MINUTES)

0

5

10

15

20

25

30

35

40

45

50

55

60
CURRENT - A

0

26.8

27.0

26.9

27.0

27.1

27.0

27.0

27.0

27.2

27.1

27.2

27.1

16
TEMPERATURE $-{ }^{\circ} \mathrm{F}$

68

100

122

139

155

168

176

184

191

196

201

205

208 


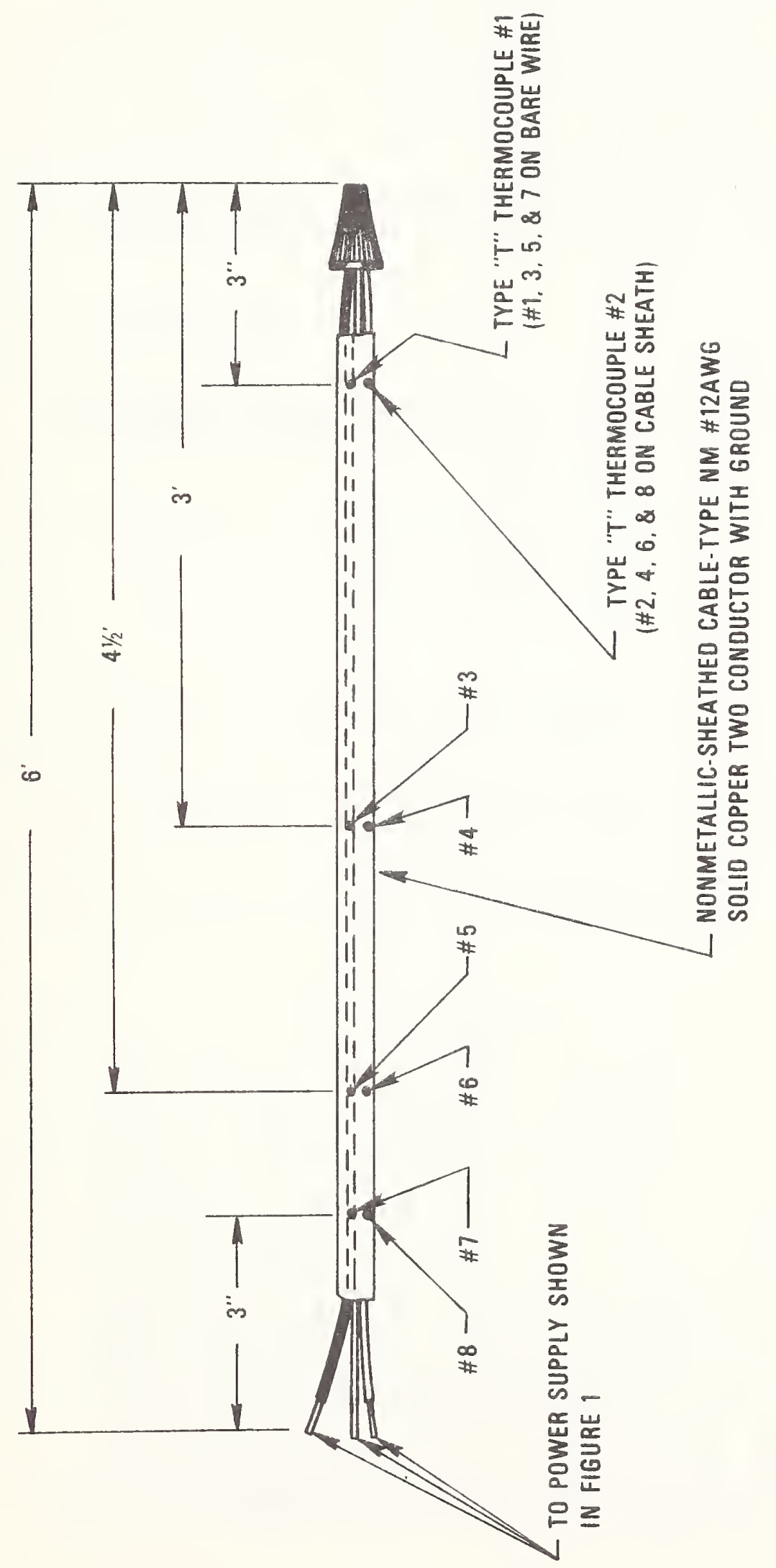

告

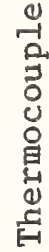

थ 


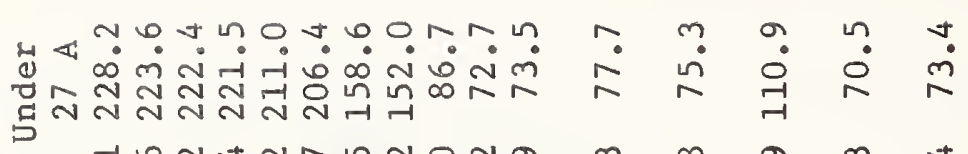

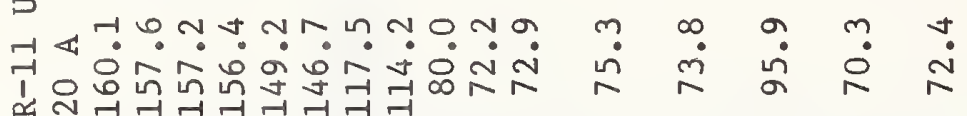

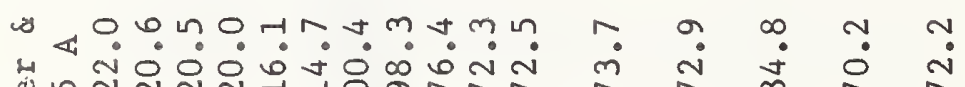

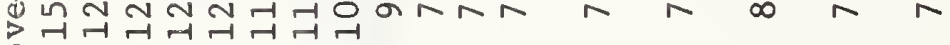

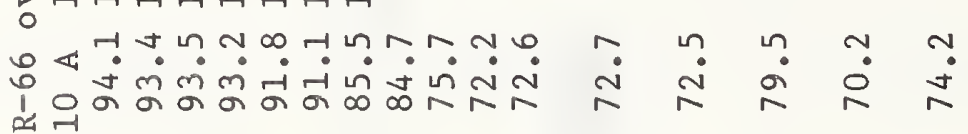

岂

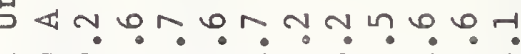

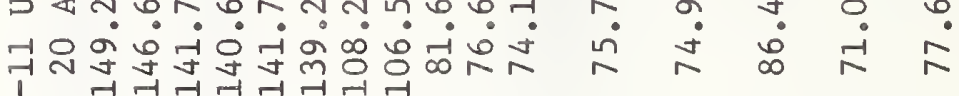
a \& $4 n+N+a m+a+10$ मुन्नન न्न $04 \pi 0$ a $00 \mathrm{~N}$ in 0 in 각요 1.

$\begin{array}{lllll}\because & n & \infty & m & 0 \\ i & n & \infty & -1 & 0\end{array}$

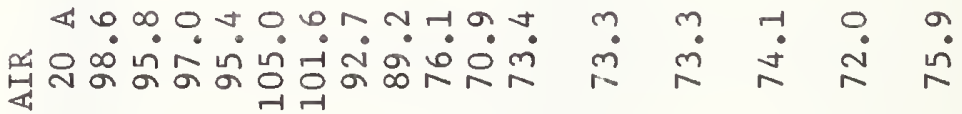

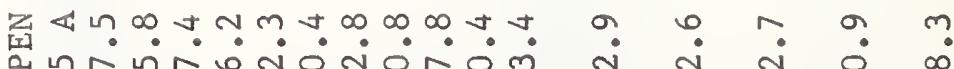

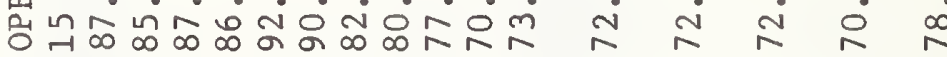
Z

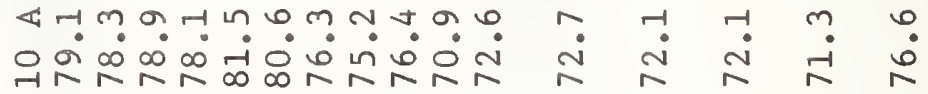

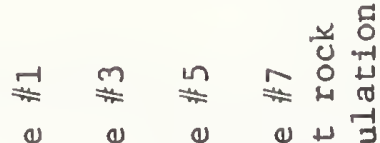

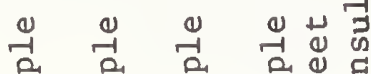

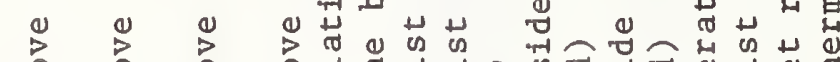

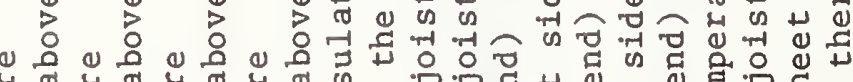
山

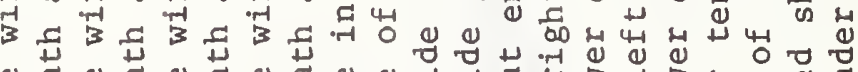

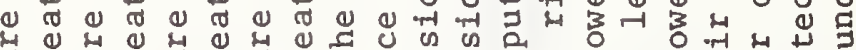

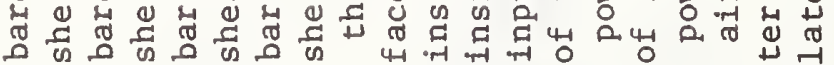

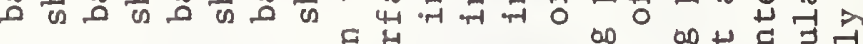

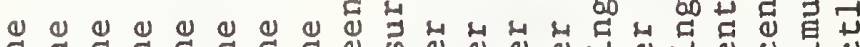

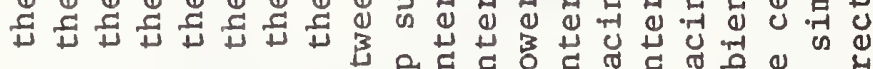

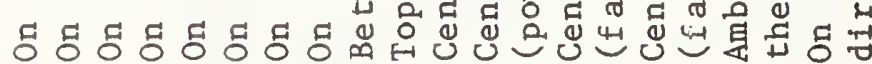




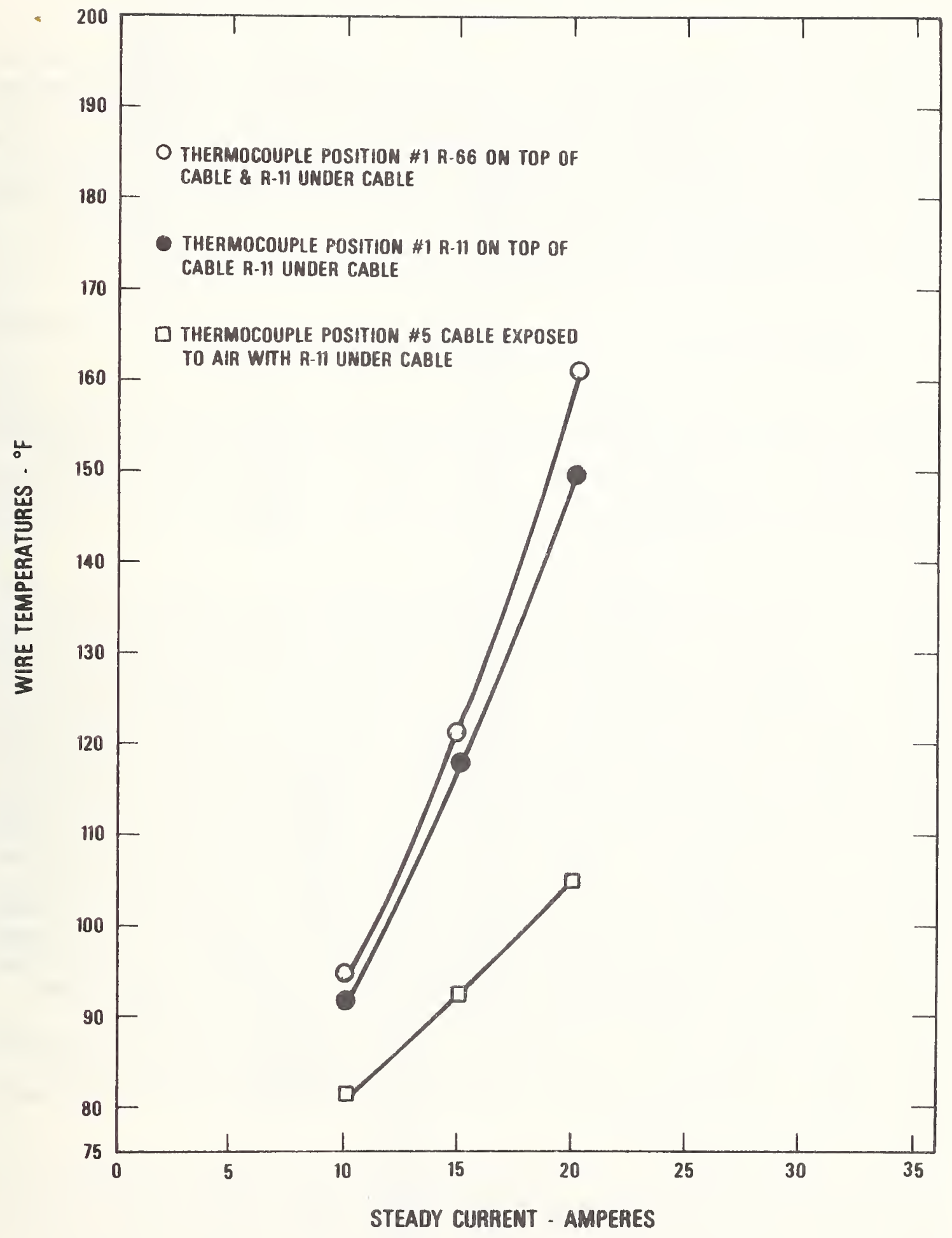

Figure 6. Highest Wire Temperatures as a Function of Current Applied to Nonmetallic-Sheathed Cable Specimen of Figure 5 


\subsubsection{Single Armored Cable in Simulated Ceiling Joist Spaces}

An armored cable specimen (type AC cable) was tested in open air, resting on one layer of R-11 glass fiber insulation to obtain cable temperatures. See Figure $\bar{T}$ for specimen description. For comparison, temperatures were obtained with the cable surrounded by insulation, with R-66 on top of the cable and $\mathrm{R}-11$ underneath the cable. The results are shown in Table 10. In this test, it was decided to surround the outlet boxes with insulation even though this would not ordinarily be done. An outlet box could become inadvertently covered in an attic space when retrofitting with additional insulation for energy conservation.

\subsubsection{Axial Heat Conduction Along Partially Thermally Insulated Branch Circuit Wiring}

A branch circuit cable can pass through relatively cool inside wall stud spaces and enter attic spaces where the cable can be covered by thermal insulation. Will that portion of the cable in the uninsulated inside wall conduct enough heat away from the portion of the cable in the attic to significantly reduce attic cable temperatures? Tests in this section attempt to answer this question.

Previous tests have been performed without electrical devices connected to lengths of cable in open air extending from lengths surrounded by building insulation. It was judged, based on calculation, that the heat transfer along the length of conductors of nonmetallic-sheathed cable (NMSC) 非12 AWG would be small and have little effect on temperatures of wiring surrounded by thermal insulation. However, to confirm this by experiment, the setup of Figure 8 was constructed. Plan view "A" of this figure shows the specimen of Figure 5 surrounded by insulation within the simulated joist space. Plan view "B" of Figure 8 shows a nine-foot addition of nonmetallic-sheathed cable to the single length shown in plan view "A". The nine-foot length of cable was folded under the insulation as shown in plan view "C". A current of 27 amperes was applied to the specimen in each plan view. The results are shown in Table 11 . As seen, the temperatures at all thermocouple positions 3 through 8 on the single length of cable were substantially unchanged by the addition of nine feet of cable. However, thermocouple positions 1 and 2 on the single cable show a significant drop in temperature with the addition of cable. Because positions 1 and 2 are close to the end of the setup and subjected to cooling by ambient air, it was judged that the drop in temperature at position 1 and 2 was caused by heat loss from the surface of the additional nine feet of cable.

Figure 9 demonstrates that the temperature of the single cable shown in plan view "A" of Figure 8 exceeds the service temperature $\left(140^{\circ} \mathrm{F}\right)$ of the cable for 20 minutes after the current to the cable had been shut off. Figure 9 is the cooling curve for both plan view "A" and plan view "B". This curve suggests that the effect of the additional cable of plan view " $B$ " on cooling the cable of plan view "A" is small. 


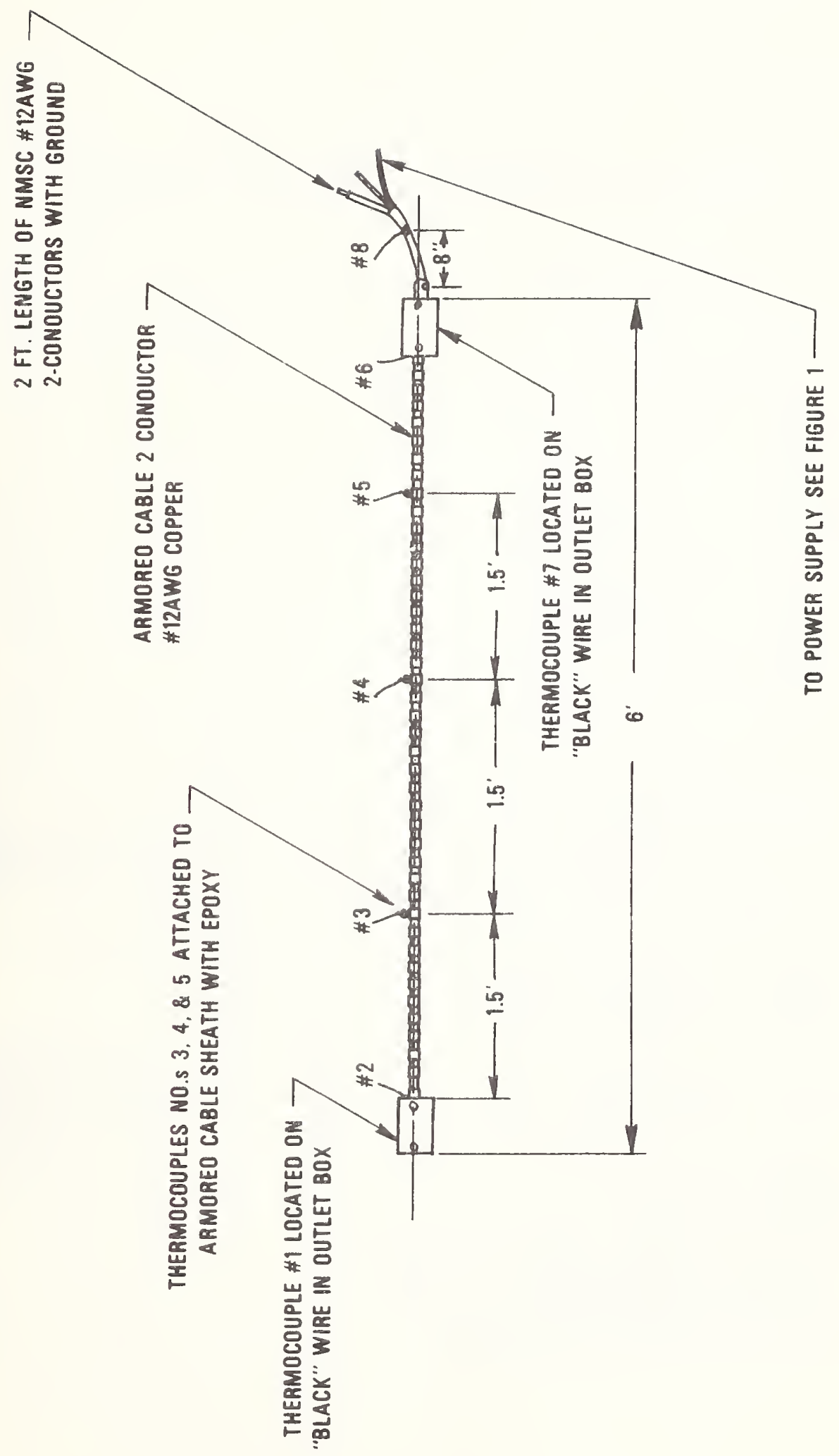

Figure 7. Armored Cable Specimen 
TABLE 10

Steady-State Temperatures on Armored Cable in Open Air and Covered wi th Thermal Insulation at $20 \mathrm{~A}$ and $27 \mathrm{~A}$

THERMO-

COUPLE 非 Thermocouple Position

1 On bare "black" wire in outlet box

2 On outlet box end

3 On armored cable sheath

$4 \quad$ On armored cable sheath

$5 \quad$ On armored cable sheath

$6 \quad$ On outlet box end

7 On bare "black" wire in outlet box

8 On nonmetallic-sheathed cable sheath

9 Between the insulation and sheet rock

10

11

12

13

14

15

16
Temperatures $-{ }^{\circ} \mathrm{F}$

In Open Air R-66 over \& $\mathrm{R}-11$ Over

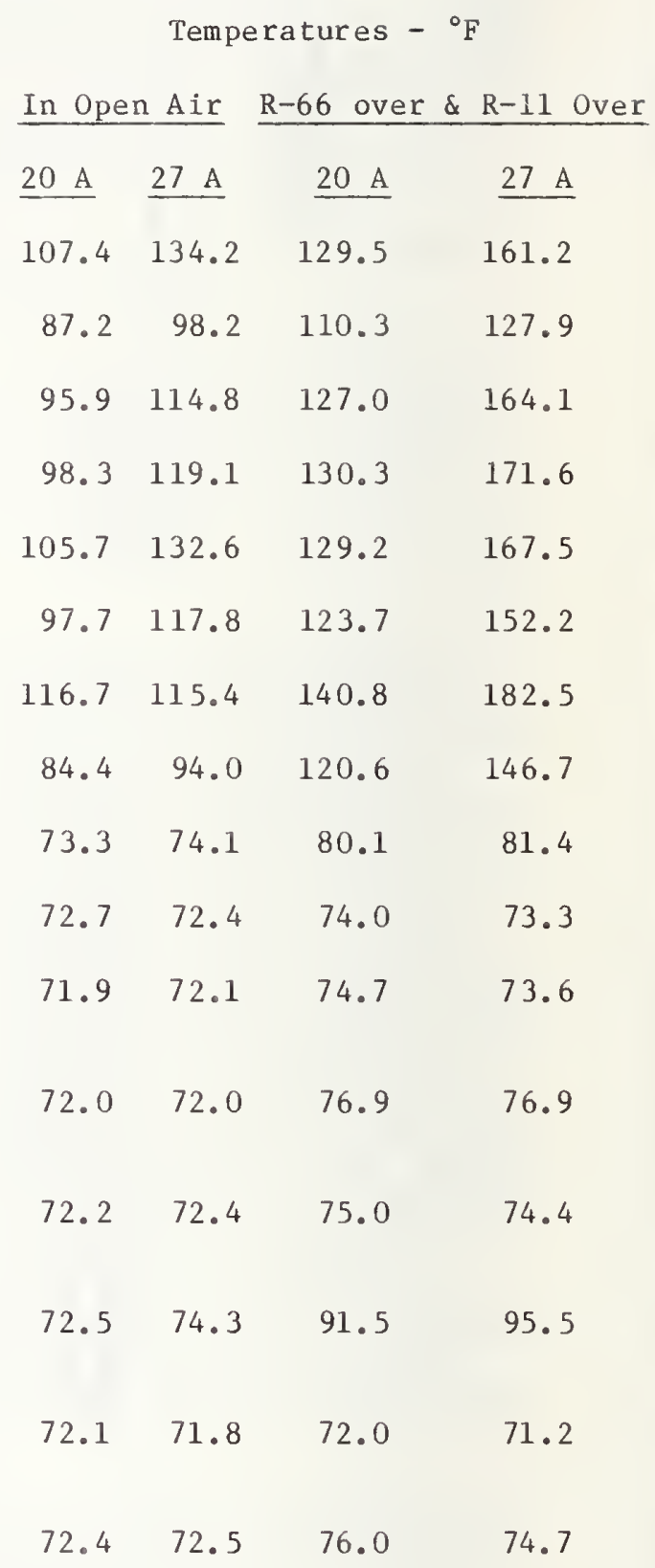

On simulated sheet rock ceiling

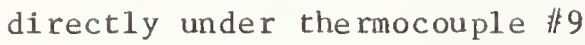



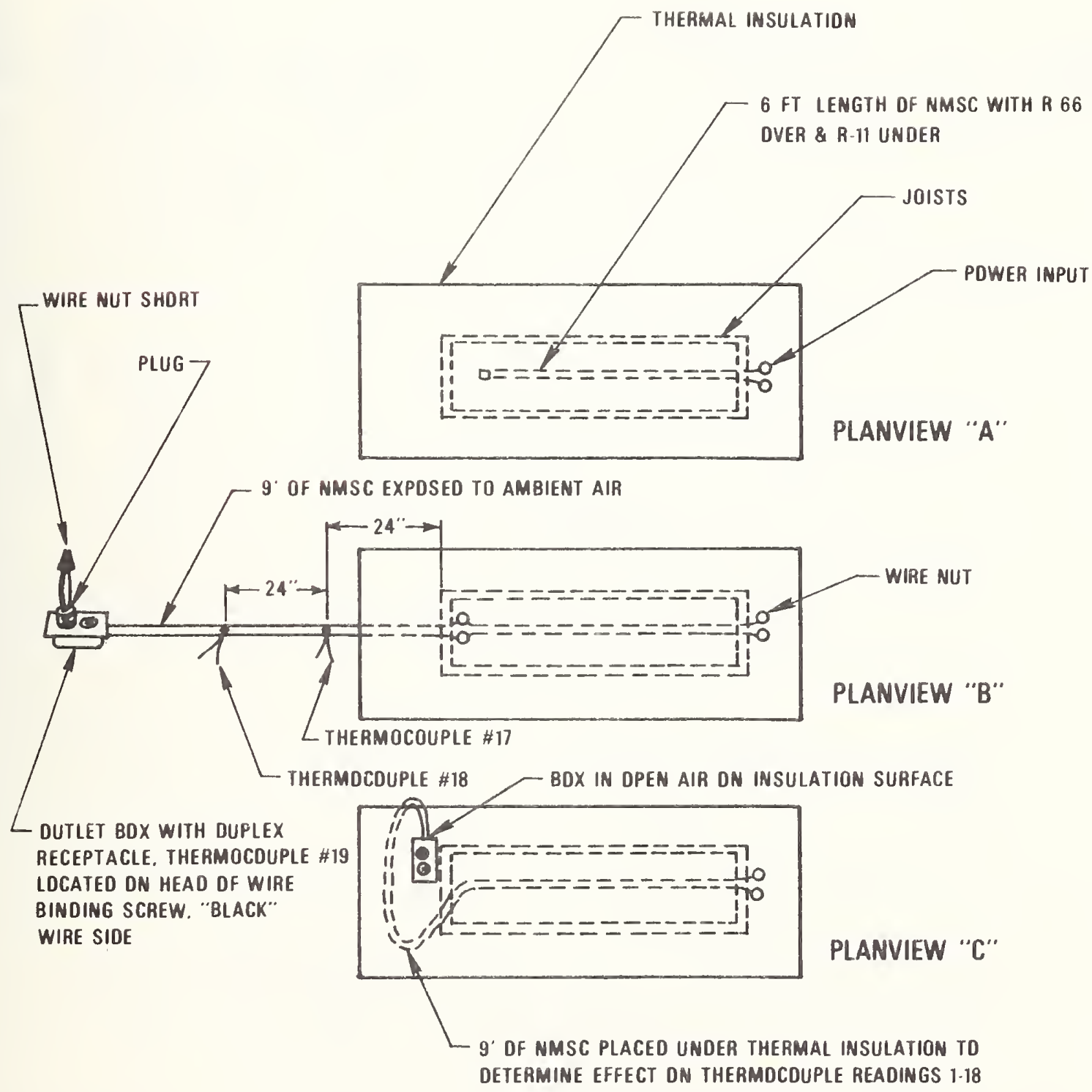

PLANVIEW "A'

Figure 8. Extended Cable Test Setup 
Effect of Additional Cable Extending into Room Temperature Air on Cable

Temperatures Under Thermal Insulation when the Current was $27 \mathrm{~A}$

\begin{tabular}{|c|c|c|c|c|}
\hline $\begin{array}{l}\text { THERMO- } \\
\text { COUPLE \# }\end{array}$ & Thermocouple Position & Single Cable & $\begin{array}{l}\text { Additional } \\
\text { Cable in Air }\end{array}$ & $\begin{array}{l}\text { Additional } \\
\text { Cable in } \\
\text { Insulation }\end{array}$ \\
\hline 1 & On the bare wire & $228.2^{\circ} \mathrm{F}$ & $169.7^{\circ} \mathrm{F}$ & $172.6^{\circ} \mathrm{F}$ \\
\hline 2 & On the sheath above thermocouple 非1 & 223.6 & 168.8 & 171.7 \\
\hline 3 & On the bare wire & 222.4 & 223.2 & 223.6 \\
\hline 4 & On the sheath above thermocouple 非 3 & 221.5 & 221.8 & 222.2 \\
\hline 5 & On the bare wire & 211.0 & 211.4 & 212.1 \\
\hline 6 & On the sheath above thermocouple 非 5 & 206.4 & 207.1 & 207.7 \\
\hline 7 & On the bare wire & 158.6 & 154.3 & 154.7 \\
\hline 8 & On the sheath above thermocouple 非 7 & 152.0 & 149.6 & 150.3 \\
\hline 9 & Between the insulation and sheet rock & 86.7 & 87.0 & 86.7 \\
\hline 10 & Top surface of the building insulation & 72.7 & 72.4 & 72.7 \\
\hline 11 & Center inside joist space end & 73.5 & 74.4 & 73.5 \\
\hline 12 & $\begin{array}{l}\text { Center inside joist space end } \\
\text { (power input end) }\end{array}$ & 77.7 & 79.6 & 78.0 \\
\hline 13 & $\begin{array}{l}\text { Center of right side joist } \\
\text { (facing power end) }\end{array}$ & 75.3 & 82.4 & 81.5 \\
\hline 14 & $\begin{array}{l}\text { Center or left side joist } \\
\text { (facing power end) }\end{array}$ & 110.9 & 96.5 & 96.7 \\
\hline 15 & $\begin{array}{l}\text { Ambient air temp. } 3^{\prime \prime} \text { above the } \\
\text { center of the joist space }\end{array}$ & 70.5 & 70.7 & 71.1 \\
\hline 16 & $\begin{array}{l}\text { On simulated sheet rock ceiling } \\
\text { directly under thermocouple 非 }\end{array}$ & 73.4 & 73.5 & 73.6 \\
\hline 17 & $2^{\prime}$ from connection on extended cable & - & 135.0 & 169.6 \\
\hline 18 & $4^{\prime}$ from connection on extended cable & - & 95.3 & 163.6 \\
\hline 19 & On side wire binding screw & - & 113.9 & 132.9 \\
\hline
\end{tabular}




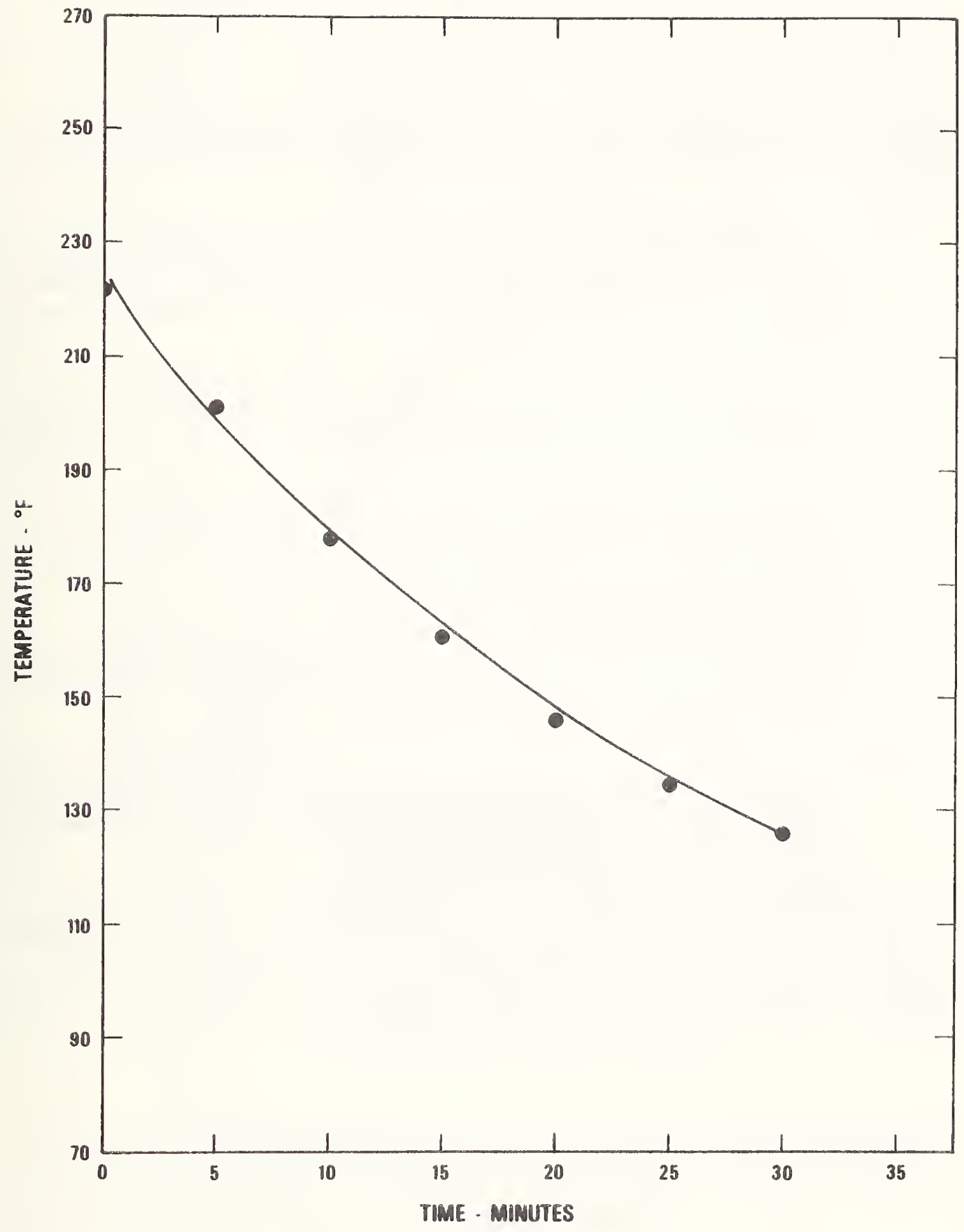

Figure 9. Cooling of Thermocouple \#4 as Shown in Table 9 with Additional Cable in Air as Shown in Figure 8 - Planview "B" 


\subsection{DISCUSSION OF CABLE TESTS IN SIMULATED ATTIC}

Figure 10 shows a comparison of the temperatures on paralleled cables carrying rated and $135 \%$ rated current while surrounded by thermal insulation. The figure demonstrates the following:

1. The temperatures on paralleled cables carrying rated current of $20 \mathrm{~A}$ surrounded by one layer of thermal insulation reached $239^{\circ} \mathrm{F}$ in 150 minutes. This temperature exceeded the maximum allowable operating temperature for nonmetallic-sheathed cable by $99^{\circ} \mathrm{F}$.

2. The temperature on paralleled cables carrying rated current of $20 \mathrm{~A}$ and exposed to ambient air temperature of $72^{\circ} \mathrm{F}$ reached $103^{\circ} \mathrm{F}$ steady temperature in 40 minutes.

3. A single length of nonmetallic-sheathed cable carrying rated current and surrounded by one layer of thermal insulation reached $152^{\circ} \mathrm{F}$ in 95 minutes and exceeded the maximum allowable operating temperature of the cable by $12^{\circ} \mathrm{F}$.

4. The temperature on paralleled nonmetallic-sheathed cables carrying $135 \%$ of rated current and surrounded by one layer of thermal insulation reached $298^{\circ} \mathrm{F}$ in 60 minutes and exceeded the maximum allowable operating temperature by $158^{\circ} \mathrm{F}$.

5. The temperature on a single length of nonmetallic-sheathed cable carrying $135 \%$ of rated current and surrounded by one 1 ayer of thermal insulation reached $208^{\circ} \mathrm{F}$ in 60 minutes and exceeded the maximum allowable operating temperature by $68^{\circ} \mathrm{F}$.

The maximum temperatures recorded on a single length of nonmetallicsheathed cable in a simulated attic space were as follows. The data are from Section 2.2.2, Table 9 of this report. The temperature, $160^{\circ} \mathrm{F}$, developed on the cable covered with $\mathrm{R}-66$ is only $11^{\circ} \mathrm{F}$ higher than the temperature, $149^{\circ} \mathrm{F}$, atveloped on the cable covered by $\mathrm{R}-11$.

In Open Air \& R-11 Under R-11 Over \& R-11 Under R-66 Over \& R-11 Under

\begin{tabular}{lllllllllll}
$10 \mathrm{~A}$ & $15 \mathrm{~A}$ & $20 \mathrm{~A}$ & $10 \mathrm{~A}$ & $15 \mathrm{~A}$ & $20 \mathrm{~A}$ & $10 \mathrm{~A}$ & $15 \mathrm{~A}$ & $20 \mathrm{~A}$ & $27 \mathrm{~A}$ \\
$81^{\circ} \mathrm{F}$ & $92^{\circ} \mathrm{F}$ & $105^{\circ} \mathrm{F}$ & $90^{\circ} \mathrm{F}$ & $118^{\circ} \mathrm{F}$ & $149^{\circ} \mathrm{F}$ & $94^{\circ} \mathrm{F}$ & $122^{\circ} \mathrm{F}$ & $160^{\circ} \mathrm{F}$ & $228^{\circ} \mathrm{F}$ \\
\hline
\end{tabular}




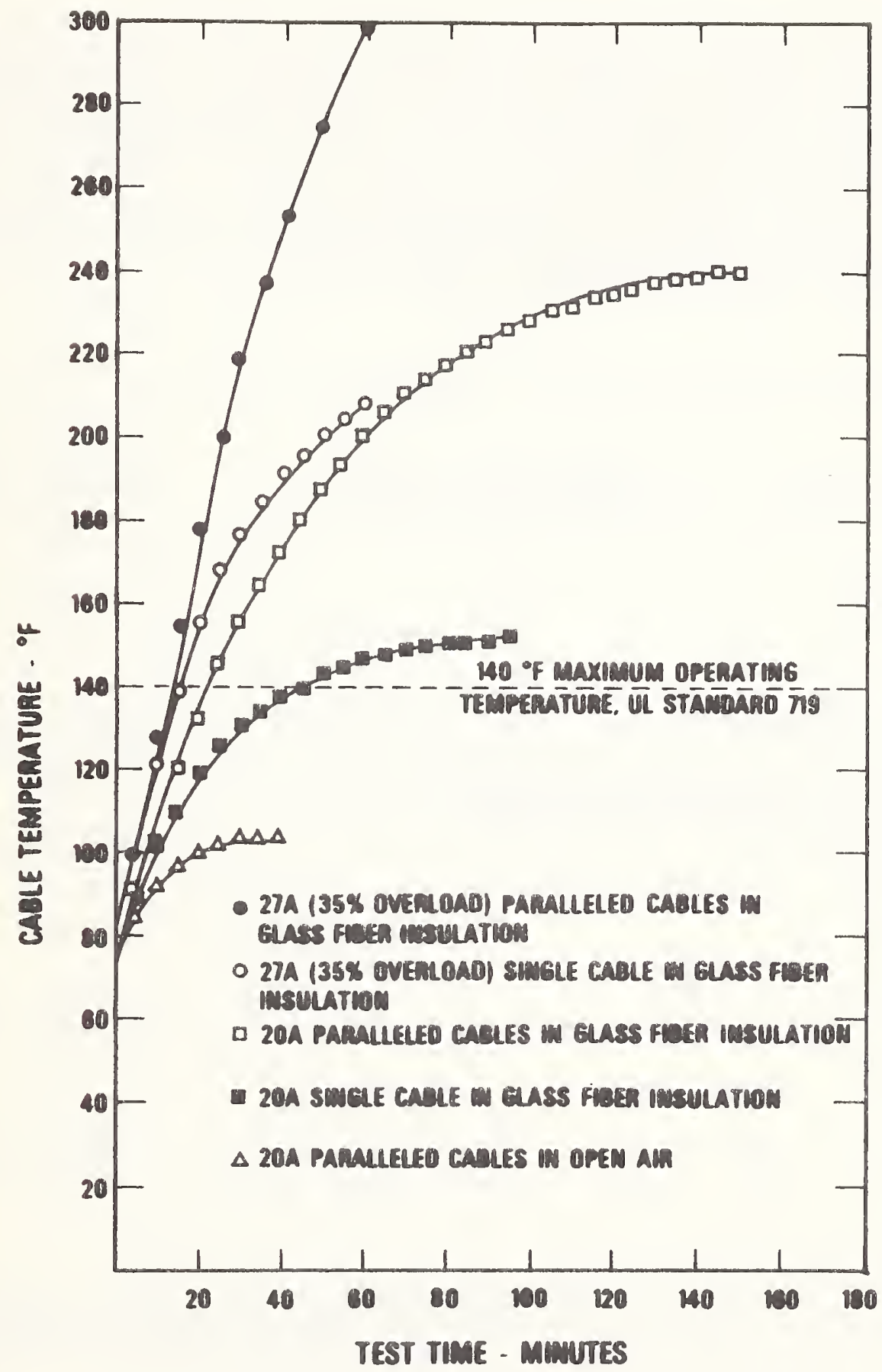

Figure 10. Comparison of Parallel Cables and Single Cable Carrying Rated or $135 \%$ Rated Currents and Surrounded by One Layer of R-11 Glass Fiber Insulation Above the Cables and One Layer of R-11 Glass Fiber Insulation Below the Cables, Including Comparison. with Cables in Open Air with One Layer of R-11 Under the Cables 
A branch circuit cable can pass through relatively cool inside wall stud spaces and enter attic spaces, where the cable can be covered by thermal insulation. Will that portion of the cable in the uninsulated inside wall conduct enough heat away from the portion of the cable in the attic to significantly reduce attic cable temperatures? Data presented in Section 2.2.4, Table 11 of this report and the following summary table indicate that significant reduction in temperature will not take place for cable carrying $135 \%$ rated current, $27 \mathrm{~A}$.

$\begin{array}{ll}\text { Additional Cable \& } \\ \text { Single Cable } & \text { Connections in Air }\end{array}$

Additional Cable \& Connection in

Thermal Insulation

$228^{\circ} \mathrm{F} \quad 223^{\circ} \mathrm{F} \quad 224^{\circ} \mathrm{F}$

During the armored cable test in simulated ceiling joist space, as presented in Section 2.2.3 and Table 10 of this report, maximum temperatures occurred in the outlet box having four 8-inch long conductors and on the cable-sheath, as shown below:

\begin{tabular}{rrrr} 
& & & \multicolumn{2}{c}{$\mathrm{R}-66$ over and } \\
\multicolumn{2}{c}{ In Air } & & \multicolumn{2}{c}{ R 11 under } \\
$20 \mathrm{~A}$ & $27 \mathrm{~A}$ & $20 \mathrm{~A}$ & $27 \mathrm{~A}$ \\
$117^{\circ} \mathrm{F}$ & $115^{\circ} \mathrm{F}$ & $141^{\circ} \mathrm{F}$ & $183^{\circ} \mathrm{F}$ \\
$98^{\circ} \mathrm{F}$ & $119^{\circ} \mathrm{F}$ & $130^{\circ} \mathrm{F}$ & $172^{\circ} \mathrm{F}$
\end{tabular}

Outlet Box Wiring Cable Sheath

Tables 9 and 10 show generally that maximum armored cable temperatures were about $50^{\circ} \mathrm{F}$ cooler than maximum nonmetallic-sheathed cable temperatures. This results from heat conduction along the metal sheath.

\section{TEST PROCEDURE AND RESULTS FOR CABLES AND OUTLET BOXES IN WALLS}

To determine temperatures on current-carrying wiring on thermal insulated walls and to determine whether or not "foamed-in" and "blow-in" thermal insulation would penetrate and fill wall outlet boxes, tests were carried 
out in three wall sections. These wall sections each contained three stud spaces and were one-half full-size wall height or four feet high.

Generally, the construction of these walls was typical of walls in residences.

The wall sections were constructed as shown in Figures 11 and 12 . Wall "A" and wall "B" were covered with sheet rock. Wall " $\mathrm{C}$ " was covered with a clear transparent plastic sheet to observe the filling process around the cables and boxes.

The type boxes and openings for thermal insulation penetration are as follows:

(a) A gangable 2-1/2 inch deep by 3 inch long by 2 inch wide steel box having side bracket and armored cable clamps had twenty holes as follows:

-- Six 0.15-inch-diameter holes

-- Two 非10-32 threaded holes

-- Eight rectangular shaped holes, 0.1 by 0.14 inch

-.. Four odd-shaped holes having an estimated area of 0.04 in $^{2}$ each.

(b) A plastic box was 1 abeled as having a volume of $20.5 \mathrm{in}^{3}$. Although this box did not have holes, it did have knockouts. With one cable entering and another leaving through knockouts, it is estimated that this box had about 0.15 in $^{2}$ through which insulation could enter.

(c) A gangable 3-1/2 inch deep by 3 inch long by 2 inch wide stee 1 box having side bracket and nonmetallic-sheathed cable clamps had eighteen holes as follows:

-..- Eight 0.1-inch-diameter holes

-- Four 0.2-inch-diameter holes

- - Two 0.24-inch-diameter holes

--- Four rectangular holes, 0.75 inch by 0.1 inch

\subsection{TEMPERATURES ON CABLES AND OUTLET BOXES}

For a range of currents, temperatures were measured on wire binding screws (torqued to twelve inch-pounds) of duplex receptacles, on outlet boxes, and on cables. Temperatures were obtained before filling the wall sections with insulation. The walls were then filled by an insulation contractor (See Appendix C concerning filling precautions). Walls "A" and " $\mathrm{C}$ " were filled with urea-formaldehyde (UF) and wall "B" was filled with 


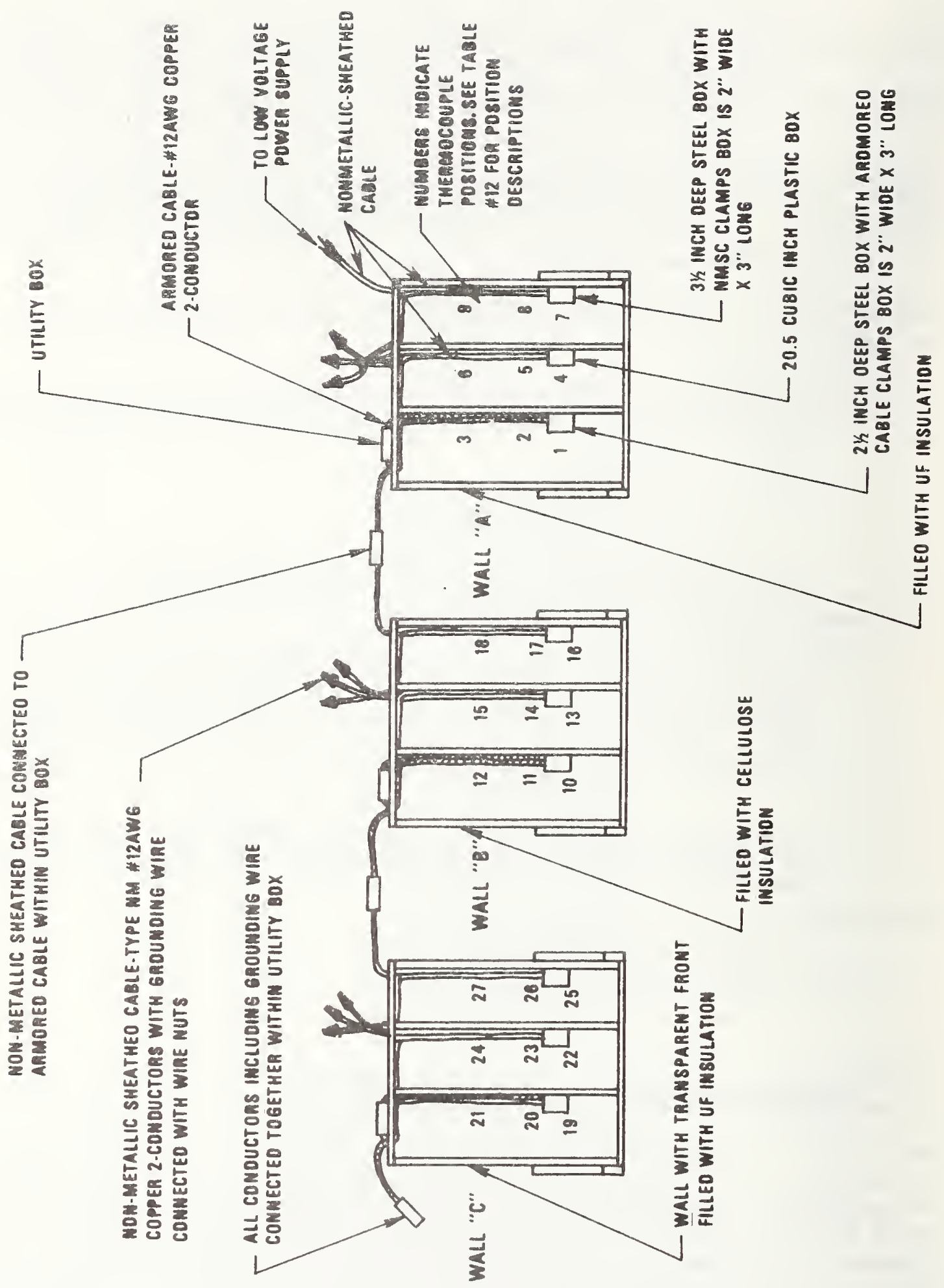

Figure 11. Backview of Wired Wall Sections 


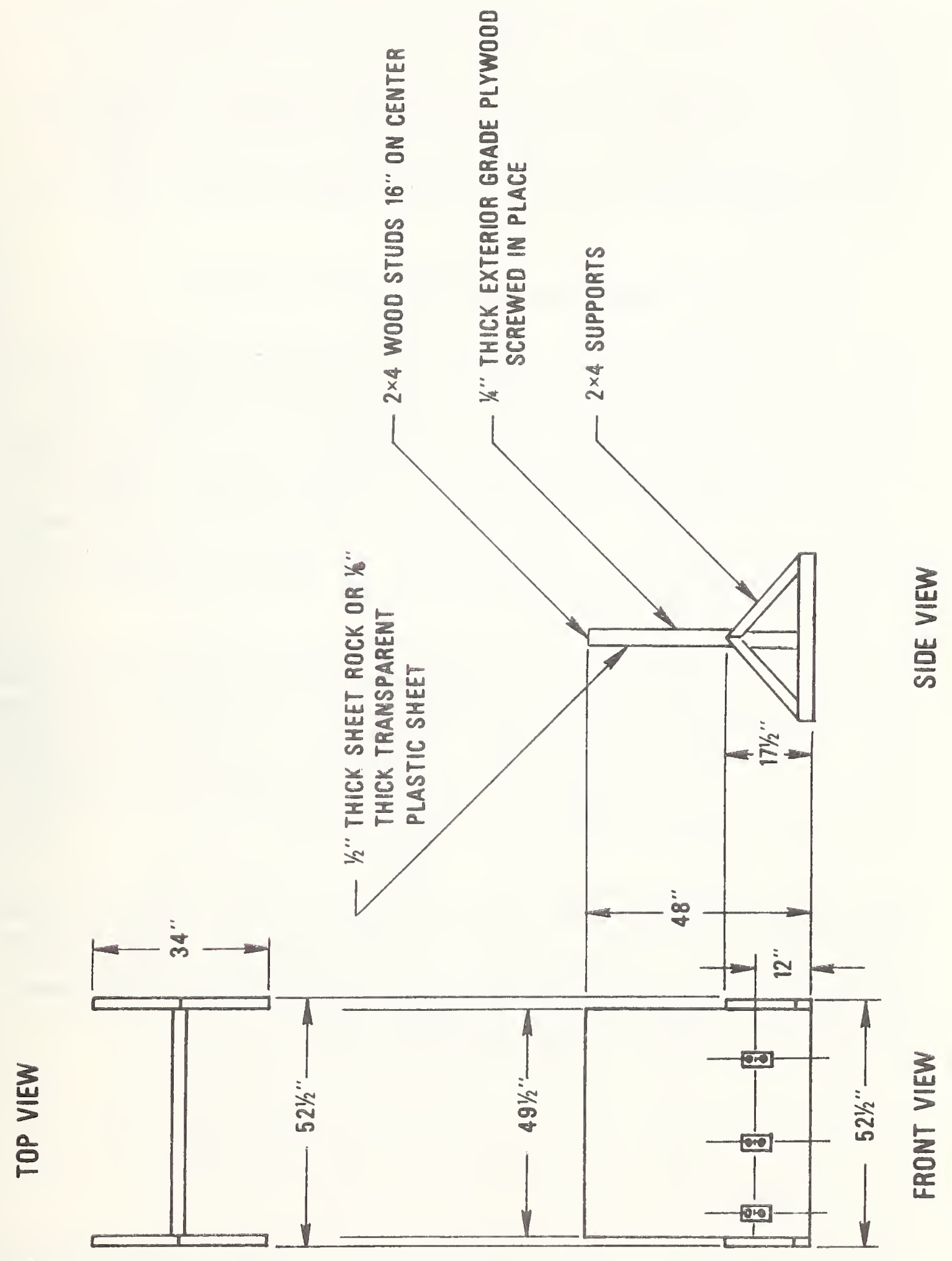

Figure 12. Single Wall Section 
cellulose*. The contractor indiated that the application density for UF insulation was $2.51 \mathrm{~b} / \mathrm{ft}^{3}$. Final dry density would be about 0.7 $1 \mathrm{~b} / \mathrm{ft}^{3}$. After filling the walls, the UF had about 65 hours to dry, at which time temperatures were obtained for comparison with currents applied prior to filling. Results are shown in Table 12. Figure 13 contrasts temperatures on the head of a wire binding screw located in the cellulose-filled wall for the same currents applied before and after filling.

\subsection{PENETRATION OF THERMAL INSULATION INTO OUTLET BOXES}

After filling walls with insulation, the wall outlet box cover plates were removed to determine if insulation had entered the outlet boxes. The UF foam stuck to and covered the back side of cover plates and filled one side of each outlet box. See photograph, Figure 14. The side of the box away from the wall stud (bracket side) contained foam so that the foam was flush with the front edge of the box. Foam was in tight contact with wire binding screws of each duplex receptacle on the "black wire side." The cellulose insulation entered all boxes. See photograph, Figure 15. The insulation was located in contact with current-carrying elements on each side of the duplex receptacles and extended to about three quarters of the height of the box.

The penetration of thermal insulation into electrical outlet boxes may be in violation of Rule 370-6 of the National Electrical Code [3]. This rule requires that boxes be of sufficient size to provide for free space for conductors enclosed in the box. The specific volume of free space which is required depends on the size and number of conductors and other devices in a box. The National Electrical Code Handbook [10] states "The purpose of these provisions is to prevent the excessive crowding of wires and splices in outlet and junction boxes."

Whether the penetration of thermal insulation into electrical outlet boxes may cause hazards or detrimental effects on the electrical system should be analyzed. Whether it is necessary to remove thermal insulation from electrical boxes for safety or functional purposes should be determined. Data are needed on dielectric characteristics, increased temperature effects, the fire hazard potential, and corrosion effects on electrical components of such installations.

* The contractor stated that the cellulose insulation was in conformance with Federal Specification HH-1-515C [9]. However, no standard was found for Urea-formaldehyde-based foam insulations. 


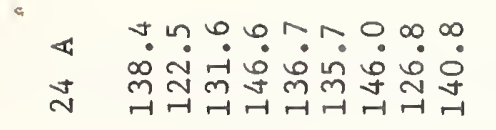

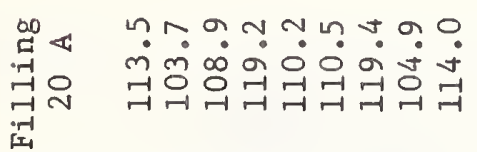

4 $40, \infty$ n $0 m \infty$ n

L n

出

4 m ก

$\stackrel{\circ}{\sim}$

ริ

离

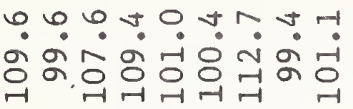

$0.0 .40,4 \pi$

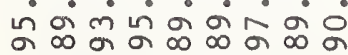

4 $\neg$ ก

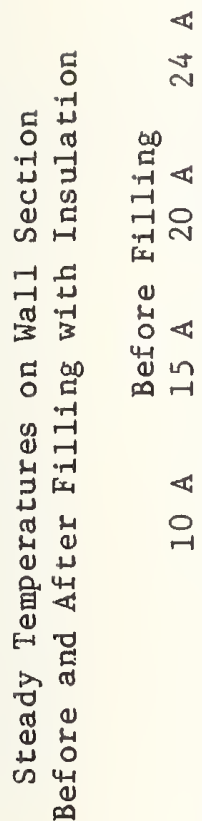

ב⿱

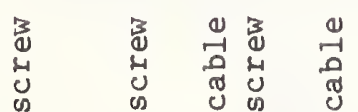

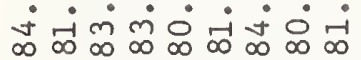
है

$\infty$ क व

豆

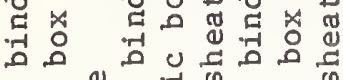

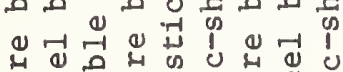

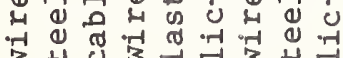

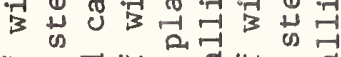

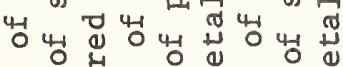

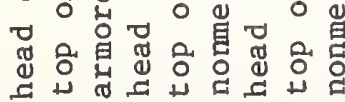

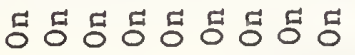

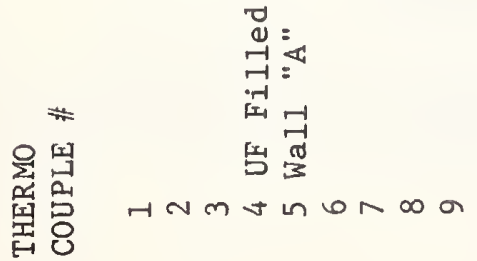

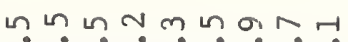
$\dot{0} \dot{0} \dot{0} \dot{0} \dot{0} \dot{0}$

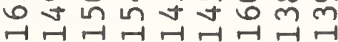

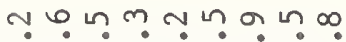
$\dot{m} \dot{m} \dot{m} \dot{-1} \dot{\sim} \dot{0}$

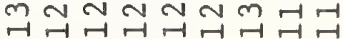

ก.

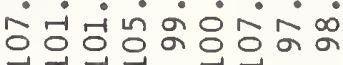

0. ก

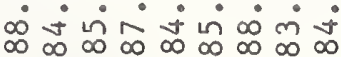

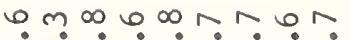
$\dot{\theta} \dot{\sim} \dot{\sim} \dot{\sim} \dot{\sim} \dot{0} \dot{0}$

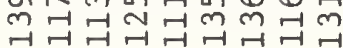
$\stackrel{m}{n}$

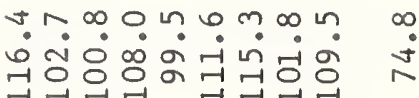

เก ต $\infty \circ \mathrm{N} \infty \mathrm{Nm}$ क नं

o $ง$ ก $\because \dot{i}$ i $\dot{0} \dot{0} \dot{0}$

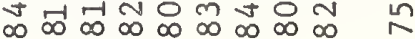

H. ก.

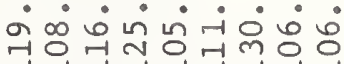

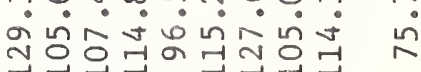
ตำตำ

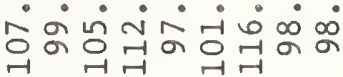

mก. ஸे

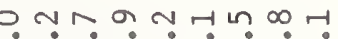
ம유

ง ○ 응 ๙

o!

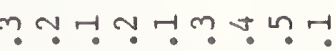
অ

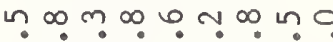
- $\dot{\sim} \dot{0} \dot{0} \dot{0} \dot{0}$ $\infty \infty \infty \infty N \infty$

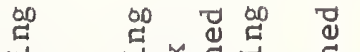

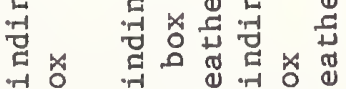
.

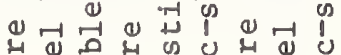

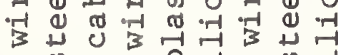

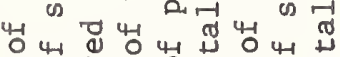

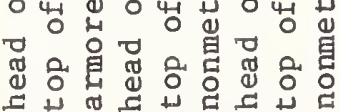
동동동동ㄷㅇㅇㄷㅇ용ㄷㅇ

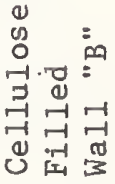

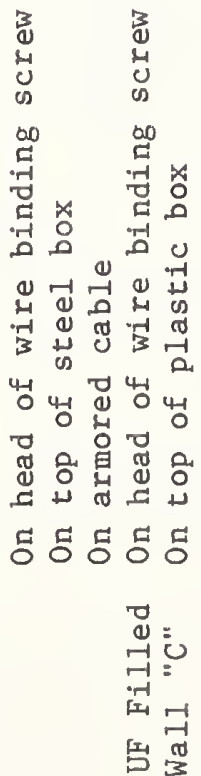

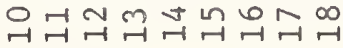

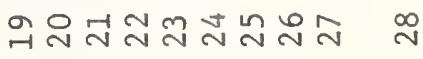




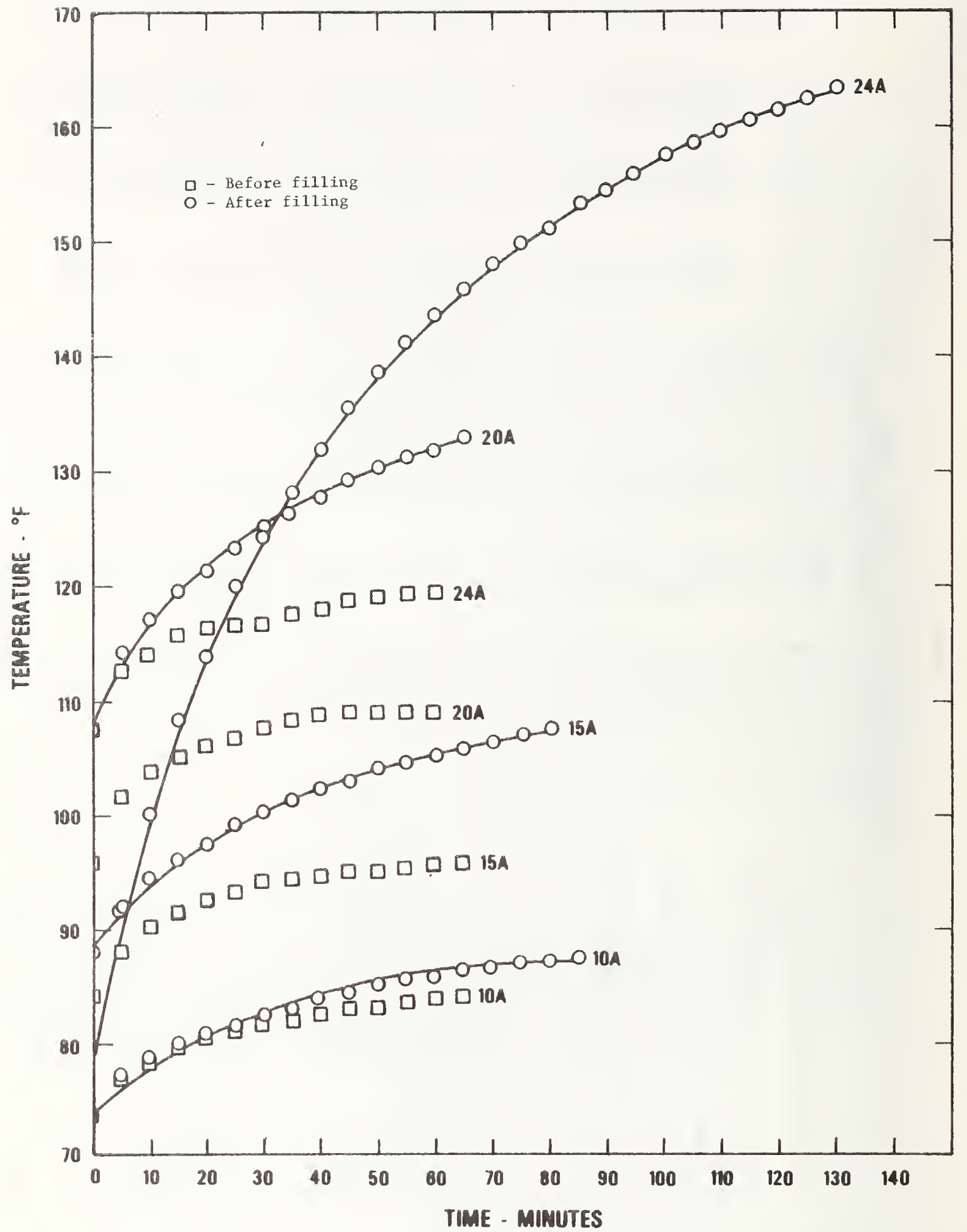

Figure 13. Cellulose Wa11, Thermocouple Position 非10, Wire Binding Screw Temperature as a Function of Time for Constant Currents 


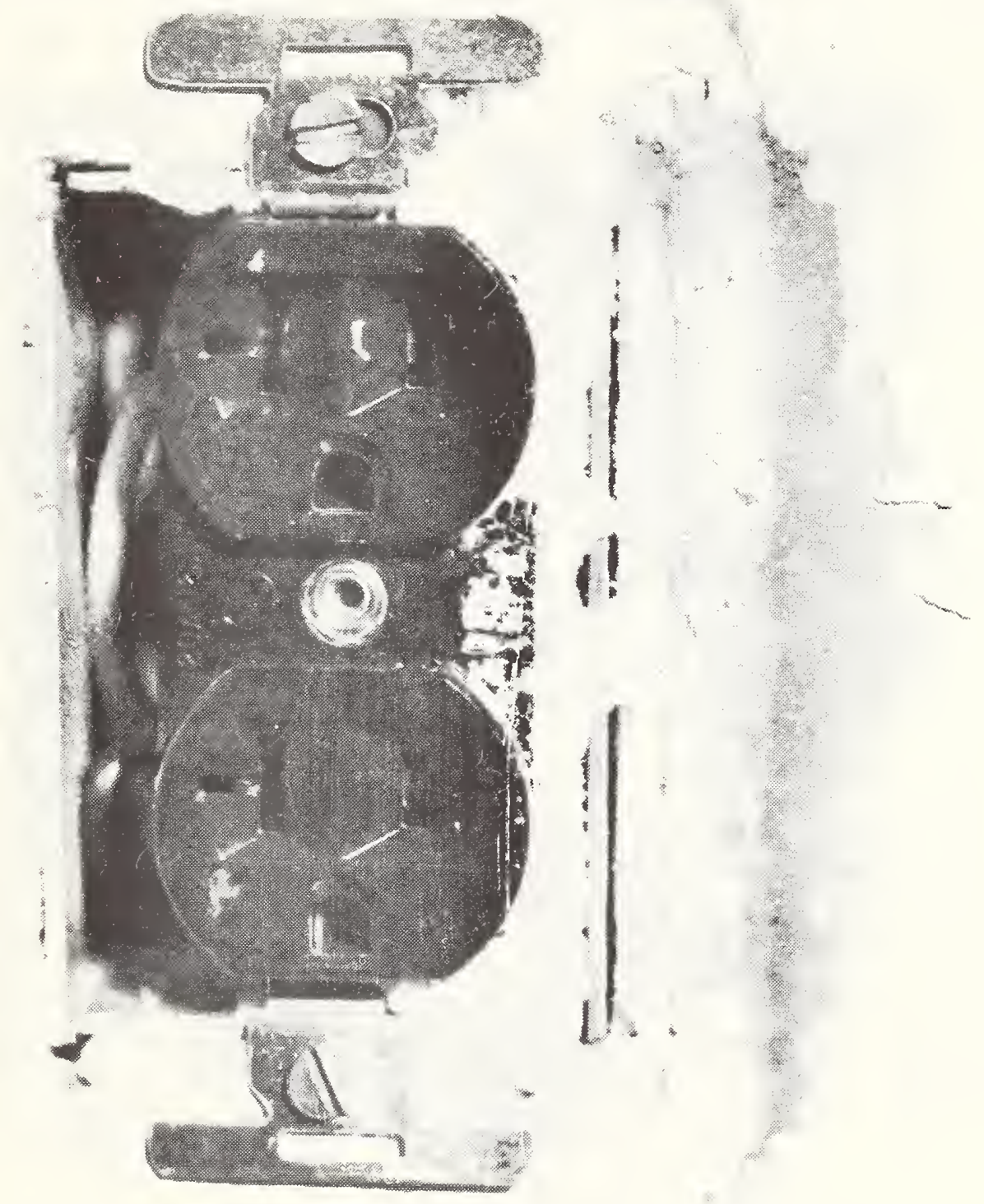

Figure 14. Penetration of Ureaformaldehyde Thermal Insulation Into Wall Outlet Box 


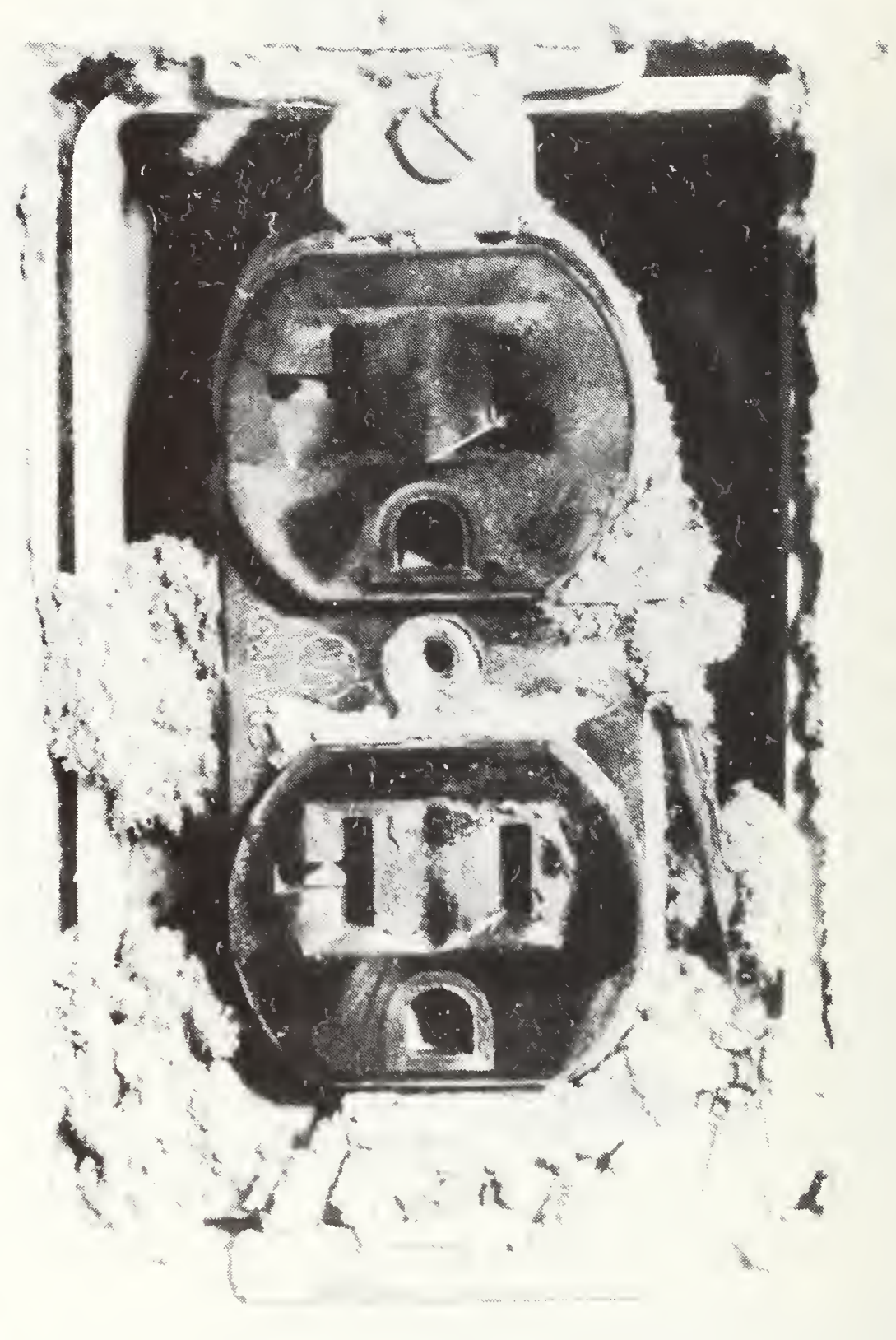

Figure 15. Penetration of Cellulose Thermal Insulation Into Wall Outlet Box 


\subsection{DISCUSSION OF TESTS OF WALL WIRING SURROUNDED BY THERMAL INSULATION}

The data presented here are from Section 3 and Table 12 of this report.

The maximum temperature of $163.5^{\circ} \mathrm{F}$ occurred on the head of a wire binding screw in the cellulose-insulated wall at 24 amperes. At 20 amperes this same screw reached only $133.2^{\circ} \mathrm{F}$.

The highest temperature in the UF insulation occurred in wall section " $A$ " with the sheet-rock cover. This temperature, $146.6^{\circ} \mathrm{F}$, occurred on the head of a wire binding screw with 24 amperes. At 20 amperes, this same screw head was $119.2^{\circ} \mathrm{F}$.

The low temperatures recorded for UF insulation suggest that the UF had not dried sufficiently to reach full insulating properties. The data presented in this report for UF were obtained 65 hours after filling the walls.

Both UF-foam and cellulose thermal building insulation penetrated outlet boxes and filled space between the walls of the box and receptacle.

\section{SUMMARY}

(a) A temperature of $298^{\circ} \mathrm{F}$ was measured on closely paralleled nonmetallic-sheathed cables carrying 135\% of rated current, $27 \mathrm{~A}$, for one hour, and located between two layers of $\mathrm{R}-11$ glass fiber insulation simulating a ceiling joist space. See Table 4. Also, a temperature of $239^{\circ} \mathrm{F}$ was measured on thermal insulationcovered parallel cables carrying rated current, $20 \mathrm{~A}$, for $21 / 2$ hours. See Table 3. These cable temperatures and some others exceeded the $140^{\circ} \mathrm{F}$ maximum allowable operating temperature of the Underwriters' Laboratories Standard for nonmetallic-sheathed cable [1] and are therefore in violation of the National Electrical Code (NEC) [3].

(b) A temperature of $208^{\circ} \mathrm{F}$ was measured on a single length of nonmetallic-sheathed cable carrying $135 \%$ of rated current, $27 \mathrm{~A}$, for one hour and located between two layers of R-11 glass fiber insulation simulating a ceiling joist space. See Table 8 . Also, a temperature of $152^{\circ} \mathrm{F}$ was measured on thermal insulationcovered cable carrying rated current, 20A, for $11 / 2$ hours. See Table 7. These cable temperatures exceed the $140^{\circ} \mathrm{F}$ maximum allowable operating temperature of Underwriters' Laboratories Standard for nonmetallic-sheathed cable [1] and are in violation of the NEC.

(c) Temperatures generated on cables during the tests presented in this report did not become high enough to ignite thermal building materials. 
(d) The insulated wiring often resulted in high temperature in violation of NEC--Article 310-9 which states: "No conductor shall be used under such conditions that its operating temperature will exceed that specified for the type of insulation involved ${ }^{[3]}$."

(e) Both UF insulation and cellulose insulation can penetrate and fill outlet boxes and contact screws of duplex receptacles contained in the boxes. This also may be in violation of the NEC.

\section{RECOMMENDATIONS}

The work presented in this paper indicates a need for a comprehensive study of temperatures that may develop on residential electrical wiring covered by thermal insulation. The recommended study should provide information concerning the potential for electrical ignition of building insulation or proximate combustibles. Evaluation and analyses of test data should provide means for consideration of performance solutions and guide criteria to prevent identified problems.

The study should also include determination of the potential for toxic gases/vapor emissions from electrical wiring at operating temperature and/or from surrounding thermal insulation.

The following briefly summarize some research tasks which should be undertaken:

(a) Field investigations of fire incidents known or suspected to have been started by electrical systems surrounded by thermal insulation should be carried out in order to better understand the problem(s).

(b) Temperature measurements on wiring in buildings (dwellings) should be carried out with various amounts/types of thermal insulation, using a range of electrical currents and ambient temperature conditions.

(c) Attempts to correlate the field data via analysis of thermal conduction and convection should be undertaken.

Laboratory investigations should include:

(1) Long-term cyclic tests of cables including cycling at slightly higher than rated currents while surrounded by thermal building insulations of various types are needed to determine if electrical insulation will fail or cause hazards. Also, during these tests, connection corrosion and/or chemical reaction between electrical insulation and thermal insulation should be studied. 
The performance of overcurrent devices and ground fault circuit interrupters should be included in cognizance of the operating requirements of overcurrent devices.

(2) Wire temperatures in thermally-insulated, full-scale structures or simulated structures with various wiring configurations, devices, and wiring methods should be studied under controlled environmental chamber conditions with various simulated electrical loads. Such data are needed for establishment of temperature/loading relationships for use in mathematical modeling and in the establishment of performance criteria.

(3) Because the service temperatures of residential branch circuit wiring (usually $60^{\circ} \mathrm{C}, 140^{\circ} \mathrm{F}$ ) appear to exceed the service temperatures of some building thermal insulations, a study should be carried out to determine wiring temperature effects on building insulation.

There appears to be uncertainty among various literature sources concerning the maximum service temperature to which ureaformaldehyde-based foams can be subjected [11]. The maximum service temperature has been given as 1 ow as $120^{\circ} \mathrm{F}$ and as high as $210^{\circ} \mathrm{F}$.

Glass-fiber insulation of residential type is for use at ambient temperatures [6]. The definition of ambient temperature was not found in the standard [6] and it is not known if the maximum operating temperature of wiring in residences, $140^{\circ} \mathrm{F}$, would be considered "ambient" temperature.

Cellulose insulation has a maximum service temperature of $180^{\circ} \mathrm{F}$. The temperature for cellulose was given on the insulation package of a manufacturer, but the temperature was not found in the standard [9].

(4) Investigations should be made to determine whether it is necessary to remove thermal insulation from electrical outlet boxes (See Section 3.2). Included should be the dielectric resistance and high voltage withstand tests for receptacles and switches when such devices and wiring are located in outlet boxes containing building thermal insulation. Such tests should be made under various environmental conditions of temperature and humidity.

(5) The possibility of arcing and subsequent tracking in thermal insulation should be investigated.

(6) The heating effects resulting from loose connections should be investigated to determine short-term and long-term effects [12]. 
(7) Failure modes in electrical circuits should be investigated for impact on thermal insulation [13-15]. 


\section{REFERENCES}

1. NONMETALLIC-SHEATHED CABLE, UL 719, Underwriter's Laboratories, Inc., June 3, 1974.

2. ARMORED CABLE, UL 4, Underwriter's Laboratories, Inc., October 2, 1974.

3. NATIONAL ELECTRICAL CODE, National Fire Protection Association, 1975.

4. MAKING THE MOST OF YOUR ENERGY DOLLARS IN HOME HEATING \& COOLING, U.S. Department of Commerce, National Bureau of Standards.

5. COPPER-WIRE TABLES, HANDBOOK 100, United States Department of Commerce, National Bureau of Standards, February 21, 1966.

6. FEDERAL SPECIFICATION HH-1-521E, Insulation Blankets, Thermal (Mineral Fiber, for Ambient Temperatures) (7-24-72).

7. MOLDED-CASE CIRCUIT BREAKERS AND CIRCUIT-BREAKER ENCLOSURES, UL 489, Underwriter's Laboratories, Inc., November 1, 1972.

8. PLUG FUSES, UL 198.5, Underwriter"s Laboratories, Inc., May 30, 1973.

9. FEDERAL SPECIFICATION HH-1-515C, Insulation Thermal (Loose-Fill for Pneumatic or Poured Application): Cellulose or Wood Fiber (4-12-76).

10. National Electrical Code Handbook, Eleventh Edition (1962) by Arthur L. Abbott and Frank Steka (McGraw-Hill).

11. UREA-FORMALDEHYDE-BASED FOAM INSULATIONS: An Assessment of Their Properties and Performance, Rossiter, Jr., W.J., Mathey, R.G., Burch, D.M., and Pierce, E.T. NBS Technical Note 946, July 1977.

12. EXPLORATORY STUDY OF GLOWING ELECTRICAL CONNECTIONS, Meese, W.J., and Beausolie1, R.W., NBSIR 76-1011, also BSS 103, July 1977.

13. SURGE VOLTAGES IN RESIDENTIAL AND INDUSTRIAL POWER CIRCUITS, by Francois D. Martzloff, IEEE Transactions of Power Apparatus and Systems, Vol. PAS-89, No. 6, July/August 1970.

14. EXPERIMENTAL DETERMINATIONS OF TEMPERATURES AND POWER LOSSES AT THE ELECTRICAL CONNECTIONS OF SOME DUPLEX RECEPTACLES, BurnS, G.W., Scroger, M.G., Beausolie1, R.W., Meese, W.J., NBSIR 77-1380, April 1978 .

15. ANALYSIS OF CODE RESTRICTIONS ON THE USE OF NONMETALLIC-SHEATHED CABLE, Meese, W.J., and Beausolie1, R.W. (NBSIR and BSS in review October 1977). 
16. DIRECT AND ALTERNATING CURRENTS, by E.A. Loew (McGraw-Hill Book Company, Inc., 4th ed., 1954. 
APPENDIX A

CALCULATION OF WIRE TEMPERATURE BASED ON INCREASE

IN WIRE RESISTANCE WITH TEMPERATURE

Experiments have shown that over a certain practical temperature range, the resistance of pure copper varies directly with the temperature as shown in the following figure [16].

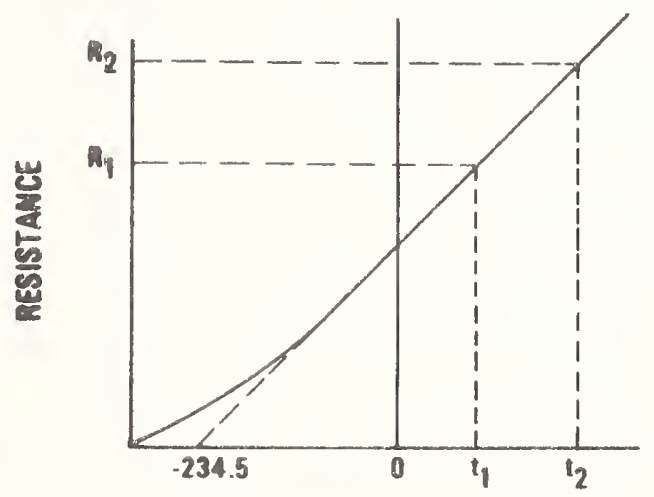

TEMPERATURE ${ }^{\circ} \mathrm{C}$

As shown, over a range copper resistance appears to be linear with a zero resistance intercept of $-234.5^{\circ} \mathrm{C}$. The temperature range used in this work was from $20^{\circ} \mathrm{C}$ to about $150^{\circ} \mathrm{C}$. Over this range a straight line 1 aw is usually assumed for resistance variation with temperature. The figure above shows that the rule of similar triangles may be applied to compute $R_{2}$ of a conductor at any temperature $t_{2}$ providing that $R_{1}$ at $\mathrm{t}_{1}$ is known, and also that the temperature intercept of the copper conductor is known. From similar triangles,

$$
\frac{R_{2}}{R_{1}}=\frac{\left(234.5+t_{2}\right)}{\left(234.5+t_{1}\right)} \text {. }
$$

Quantities such as $\left(234.5+t_{1}\right)$ and $\left(234.5+t_{2}\right)$ can be considered "apparent absolute temperature [16]".

$$
\mathrm{t}_{2}=\frac{\mathrm{R}_{2}}{\mathrm{R}_{1}}\left(234.5+\mathrm{t}_{1}\right)-234.5
$$


For the work presented in this report, $R_{1}$ for the wire specimens was determined with a kelvin bridge ohmmeter and $t_{1}$ was determined from initial wire temperature measurement. $R_{2}$ was determined from the final recorded current and voltage drop across the specimen. The following presentation in Table 13 shows fair agreement between measured temperatures and calculated temperatures. As a general rule, calculated temperature was lower than measured temperature. This is judged to be the result of variation in the tightness of the thermal insulation against the specimen; and also, due to some minimal effect of heat transfer along the conductors and venting of ambient air, perhaps through voids between insulation batts and wiring. Temperatures in the following Table 13 were taken on electrical insulation of cable jacket. Therefore, some disagreement can be attributed to this. However subsequent tests have indicated that temperature drop through the electrical insulation was only several degrees $\mathrm{F}$.

Table 13. Comparison of Calculated and Measured Temperatures

Table No. In This Report
Maximum

Maximum Temperature
Temperature Calculated
Final

Voltage Drop
Initial Temperature
Initial

Resistance

$\left({ }^{\circ} \mathrm{F}\right)$

$\left({ }^{\circ} \mathrm{F}\right)$

(Amperes)

(Volts)

$\left({ }^{\circ} \mathrm{F}\right)$

(Ohms)

\begin{tabular}{lllllll}
\hline 2 & 103 & 109 & 20.3 & 1.266 & 72 & 0.0577 \\
3 & 239 & 206.2 & 20.3 & 1.510 & 74 & 0.0579 \\
4 & 298 & 274.6 & 26.8 & 2.23 & 71 & 0.0577 \\
\hline
\end{tabular}




\section{APPENDIX B}

\section{CHEMISTRY TESTS AT NBS FOR GASES AND/OR VAPORS FROM HEATED CABLES AND THERMAL INSULATION}

The Bioorganic Section of NBS's Analytical Chemistry Division attempted to determine if noxious fumes were given off when nonmetallic-sheathed cable (NMSC) and thermal insulation were heated to greater than $200^{\circ} \mathrm{F}$. The preliminary tests of small samples were inconclusive. The test procedure, results and conclusions are summarized below.

The analytical scheme involved heating the cable and insulation in a closed system, trapping any volatile organics on a liquid $\mathrm{N}_{2}$ cold finger for subsequent mass spectrometric identification. The apparatus built for trapping the compounds is shown in the sketch.

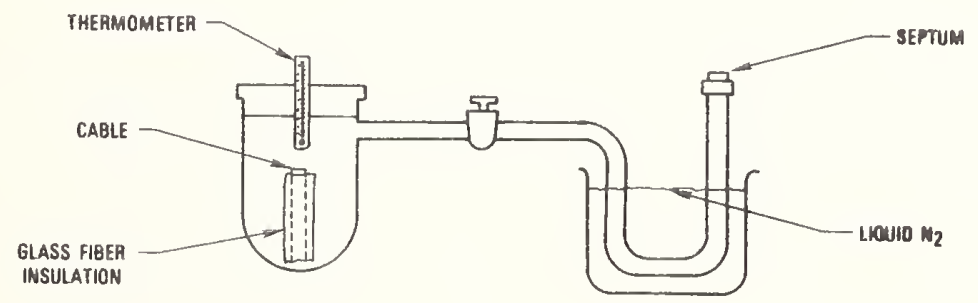

A $6 \mathrm{~cm}$ piece of NMSC was placed into the vessel between small pieces of insulation. The stopcock was opened and the temperature in the vessel raised to $200^{\circ} \mathrm{C}$ with heating tape. The first analysis involved bringing the U-tube up to room temperature and sampling the headspace vapor in the U-tube. A gas withdrawn was injected into the Heated Expansion Volume on a Hewlett Packard 5930A Mass Spectrometer. The sample was then passed through a leak into the ion source where electron impact spectra (70ev) were scanned repetitively every three seconds (m/e34400). The spectra were stored on magnetic disk (HP5933A Data System) where they were available for subsequent interpretation.

In a second experiment, the U-tube was connected directly to the Heated Expansion Volume with the use of a 26-gauge needle and an adapter. The sample was leaked through a valve into the ion source of the mass spectrometer where electron impact spectra were again recorded under computer control. In order to aid the transfer of volatile components through the small conductance of the 26-gauge needle, heat was applied to the U-tube with a hot air gun as the spectra were being recorded.

Mass spectra recorded during each run showed no significant peaks other than $\mathrm{m} / \mathrm{e} 40$ argon and 44 carbon dioxide which arose from the air background in the Heated Expansion Volume and/or the ion source. These preliminary experiments indicate that additional steps are necessary 
to concentrate the evolved gases prior to mass spectrometric identification. Also, some sort of fractionation or separation step will be required in order to resolve the expected mixture of gases into pure components prior to introducing them to the mass spectrometer. 


\section{APPENDIX C \\ PRECAUTIONS DURING INSTALLATION OF \\ "FOAMED-IN" AND "BLOWN-IN" THERMAL INSULATION}

There is a considerable quantity of water in ureaformaldehyde (UF) based foam thermal insulation; consequently, wet foam may subject the applicator to possible electric shock. The risk of electric shock to the applicator should be analyzed and, if necessary, adequate safety precautions developed. The potential hazard of electric shock to installer by possible penetration of wiring while drilling holes into building walls for insulation application should be analyzed. Whether precautions are necessary such as turning off electric power during installation should be determined. Also, the possibility of damage to wiring by drilling holes should be determined. 



\begin{tabular}{|c|c|c|c|}
\hline $\begin{array}{l}\text { U.S. PEPT. OF COMM. } \\
\text { BIBLIOGRAPHIC DATA } \\
\text { SHEET }\end{array}$ & $\begin{array}{l}\text { 1. PUBLICATION OR REPORT NO. } \\
\text { NBSIR } 78-1477\end{array}$ & $\begin{array}{l}\text { 2. Gov't Accession } \\
\text { No. }\end{array}$ & 3. Recipient's Accession No. \\
\hline \multicolumn{3}{|l|}{ 4. TITLE AND SUBTITLE } & $\begin{array}{l}\text { 5. Publication Date } \\
\text { July } 1978\end{array}$ \\
\hline \multicolumn{3}{|c|}{$\begin{array}{l}\text { EXPLORATORY STUDY OF TEMPERATURES PRODUCED BY SELF-HEATING } \\
\text { OF RESIDENTIAL BRANCH CIRCUIT WIRING WHEN SURROUNDED BY } \\
\text { THERMAL INSULATION }\end{array}$} & 6. Performing Organization Code \\
\hline \multicolumn{3}{|l|}{$\begin{array}{l}\text { 7. AUTHOR(S) } \\
\text { R. Beausolie1, W. }\end{array}$} & 8. Performing Organ. Report No. \\
\hline \multicolumn{3}{|c|}{ 9. PERFORMING ORGANIZATION NAME AND ADDRESS } & $\begin{array}{l}\text { 10. Project/Task/Work Unit No. } \\
4621204\end{array}$ \\
\hline \multicolumn{3}{|c|}{$\begin{array}{l}\text { DEPARTMENT OF COMMERCE } \\
\text { WASHINGTON, D.C. } 20234\end{array}$} & 11. Contract/Grant No. \\
\hline \multirow{2}{*}{\multicolumn{3}{|c|}{ 12. Sponsoring Organization Name and Complete Address (Street, City, State, ZIP) }} & $\begin{array}{l}\text { 13. Type of Report \& Period } \\
\text { Covered }\end{array}$ \\
\hline & & & $\frac{\text { Final }}{\text { 14. Sponsoring Agency Code }}$ \\
\hline
\end{tabular}

\section{SUPPLEMENTARY NOTES}

16. ABSTRACT (A 200-word or less factual summary of most significant information. If document includes a significant bibliography or literature survey, mention it here.)

The purpose of the work presented in this paper was to make preliminary determination under laboratory conditions of temperatures that might develop on residential electrical wiring covered by thermal insulation when carrying rated currents or currents slightly above rated values.

The results show that temperatures on conductors surrounded by thermal insulation can greatly exceed the maximum service temperatures for the wire insulation. Results also show that some types of insulation currently used to retrofit buildings may fill wall outlet boxes and contact the current carrying elements and connections of duplex receptacles.

This study indicates need for a concentrated study of temperatures that might develop on residential electrical wiring covered by thermal insulation.

17. KEY WORDS (six to twelve entries; alphabetical order; capitaltze only the first letter of the first key word unless a proper name; separated by semicolons) Branch circuit wiring; electrical fires; heat generation in receptacles; insulated buildings; overheating conductors; residential branch circuit wiring; thermal insulation and electrical wiring.

\section{AVAILABILITY Unlimited}

[] For Official Distribution. Do Not Release to NTIS

[] Order From Sup. of Doc., U.S. Government Printing Office Washington, D.C. 20402, SD Cat. No. C13

[X] Order From National Technical Information Service (NTIS) Springfield, Virginia 22151

\begin{tabular}{|l|c|}
\hline $\begin{array}{l}\text { 19. SECURITY CI.ASS } \\
\text { (THIS REPURT) }\end{array}$ & 21. NO. OF PAGES \\
UNCL ASSIFIED & 52 \\
\hline $\begin{array}{l}\text { 20. SECURITY CLASS } \\
\text { (THIS PAGE) }\end{array}$ & 22. Price \\
UNCLASSIFIED & $\$ 5.25$ \\
\hline
\end{tabular}





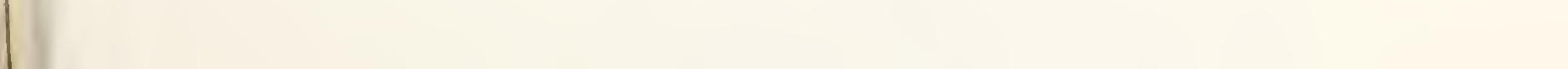


